\title{
NORMAS DE APLICAÇÃO IMEDIATA COMO UM MÉTODO PARA O DIREITO INTERNACIONAL PRIVADO DE PROTEÇÃO DO CONSUMIDOR NO BRASIL'
}

\author{
Cláudia Lima Marques ${ }^{2}$ \\ Daniela Corrêa Jacques ${ }^{3}$
}

Introdução; I. As Normas de Aplicação Imediata Em Matéria de Consumo: Uma Materialização do DIP Brasileiro?; 1.A Terminologia "Normas de Aplicação Imediata"; 2. Normas de Aplicação Imediata, Materialização e Pluralidade de Métodos em DIP; 11. A Utilização das Normas de Aplicação Imediata para a Proteção do Consumidor Brasileiro; 1.O Código de Defesa do Consumidor - Lei 8.078/90 Como Lei de Aplicação Imediata: A Opinião da Doutrina em Matéria de Comércio Eletrônico; 2.Análise do Caso Panasonic; Considerações Finais.

\section{INTRODUÇÃO}

Em suas conferências na Universidade Federal do Rio Grande do Sul, em 2002, António Marques dos Santos, ${ }^{4}$ ressaltava a relativização do método conflitual clássico e a hoje existente pluralidade de métodos em Direito Internacional Privado (DIP), explicando as "normas de aplicação imediata" como uma nova forma de solucionar as situações multiconectadas ou jusprivatistas internacionais. ${ }^{5}$ Para

Trabalho em homenagem à António Marques dos Santos. Nosso reconhecimento e agradecimento ao grande jutista e professor lusitano, Prof. Dr. António Marques dos Santos (Univ. de Lisboa). De inteligência, espitito público e humanismo privilegiados, demonstrou sempre especial carinho pelo Brasil e pela Universidade Federal do Rio Grande do Sul.

2 Professora Titular de Direito Internacional Privado da Universidade Federal do Rio Grande do Sul - Porto Alegre, Brasil. Doutora em Direito (Heidelberg), Mestre em Direito (Tübingen), Especialista em Direito Europeu (Europa-Institut, Saarbrücken). Ex-presidente do Brasilcon - Instituto Brasileiro de Política e Direito do Consumidor (São Paulo). Directeur da Association International de Droit de la Consommation (Bruxelas).

3 Advogada; Mestre e Especialista em Direito Internacional pela Universidade Federal do Rio Grande do Sul - Brasil.

4 Veja detalhes em sua famosa obra, MARQUES DOS SANTOS, António. As normas de aplicação imediata no direito internacional privado- Esboço de uma teoria geral, Coimbra: Almedina, 1991, p. 2 e seg.

- Para uma bibliografia de António Marques dos Santos, veja MALHEIROS, Manuel, António Marques dos Santos - um homen no seu tempo, in IAYME, Erik e SCHINDLER, Christian, Portugiesisch - Weltsprache des Rechts, Aachen: Shaker Verlag, 2004, p. 33- 39 
homenagear este grande mestre do Direito Internacional Privado lusitano, escolhemos justamente analisar as normas de aplicaçāo imediata, em especial o Código Brasileiro de Defesa do Consumidor (Lei 8.078/90), verificando se, em seu largo uso jurisprudencial no Brasil, ${ }^{6}$ constitui ou não um novo método para o direito internacional privado visando a proteção do consumidor nas suas relações conectadas em abstrato com mais de uma ordem jurídica. ${ }^{7}$

Segundo Nádia de Araújo, "as regras consideradas como de aplicação imediata (lois de police) são aquelas cujo conjunto é considerado como do domínio de regulamentação estatal e que por todos deve ser seguido, para salvaguardar a organizaão política, social ou econômica do país." ${ }^{8}$ Assim o Artigo $3^{\circ}$, alínea $1^{\text {a }}$ do Código Civil Francês dispõe que algumas leis e normas obrigam a todos, nacionais e estrangeiros, no território francês: "Les lois de police et de sûreté obligent tous ceux qui habitent le territoire." Uma norma material, imperativa, para todos os casos -mesmo os de DIP- no território.

Se algum tempo atrás a proteção do consumidor era um tema de direito interno também no Brasil, pois a atuação da maioria das pessoas restringiamse ao território do seu país, uma relação típica nacional, sem qualquer elemento de internacionalidade, ${ }^{9}$ hoje a realidade é diversa. ${ }^{10}$

A proteção internacional do consumidor é hoje um dos temas mais atuais do Direito Internacional Privado, ${ }^{11}$ seja pela crescente influência da legislação da Uniāo Européia, ${ }^{12}$ pela banalização do consumo internacional, ${ }^{13}$ e não poucos se preocupam com o eventual retrocesso no nível de proteção deste

- Veja os leading cases de proteção do consumidor no Brasil, in MARQUES, Cláudia Lima, BENIAMIN, Antônio $H$. de $V$. e MIRAGEM, Bruno, Comentários ao Código de Defesa do Consumidor-Art. 1 a 74 Aspectos materiais, São Paulo: RT, 2004, p. 56 e seg.

7 Sobre o tema veja também o livro dedicado im memoriam à António Marques dos Santos, MARQUES, Cláudia Lima, Confiança no comércio eletrônico e a proteção do consumidor, São Paulo: Editora Revista dos Tribunais, 2004, p. 31 e seg.

: ARAÚJO, Nádia, Contratos Internacionais, 2.ed., Rio de Janejro: Renovar, 2000, p. 33.

9 Assim ensina HOFFMAN, Bend von, Uber den Schutz des Schächeren bei internationalen Schuldvertragen, in RabelsZ 38 (1974), p. 401, explicando que nos casos excepcionais se podia usar a cláusula de ordem pública para proteger este "mais fraco".10 Veja RIZ7ZATTO NUNES, Luiz Antônio, Comentários ao CDC, Saraiva, São Paulo, 2000, p. 349.

10 Veja RIZZATTO NUNES, Luiz. Antônio. Comentários ao CDC. Saraiva, São Paulo, 2000, p. 349.

1) Assim também MANKOWISKI, Peter. Entwicklung in Internationalen Privat- und Prozessrecht 2003/2004 (Teil 1), in RIW 7/2004, p. 482-483 e LAGARDE, Paul, Développements futurs du D.I.P., in RabelZ 68 (2004), p. 226.

12. Veja, por exemplo, em material de contratos, SCHLACHTER, Monika, Verbraucherschutz gegen Strukturvertriebsmodelle: gemienschaftsrechtliche Anforderungen na ein effektives Widerrufsrecht, in RIW 9/2004, p. 655-662. E, em material de delitos, SIEMS, Mathias M., Die Harmonisierung des Internationalen Deliktsrechts und die 'Einheit der Rechtsordnung', in RIW 9/2004, p. 662 e seg.

4 Veja, sobre jogos e loterias ou promessas de 'ganhos' no estrangeiro, como novo problema europeu, Hacker, Robert, Europäisch-zivilverfahrechtliche und international-privatrechtliche Probleme grenzüberschreitender Gewinnzusagen-zugleich zu einem europäischen Begriff der unerlaubten Handlug, in ZVglRWiss 103 (2004), p. 463-500. 
sujeito vulnerável, ${ }^{14}$ seja em direito material, ${ }^{15}$ seja, metodologicamente, ${ }^{16} \mathrm{em}$ Direito Internacional Privado. ${ }^{17}$

Os bens estrangeiros estão nos supermercados, os serviços são oferecidos por fornecedores com sede no exterior no telemarketing, através da televisão, do rádio, da internet, da publicidade massificada no dia-a-dia da maioria dos cidadãos de nossas metrópoles regionais. ${ }^{18}$ Não é mais necessário viajar, ser um consumidor-ativo, um consumidor turista, deslocar-se para ser um consumidor, que contrata de forma internacional ou se relaciona com fornecedores de outros países. ${ }^{19}$ As próprias formas de produção e montagem hoje são internacionais, os contatos internacionais de consumo e o turismo massificaram-se. ${ }^{20}$

i4 A definiçăo de consumidor, conforme assevera Toniollo, no ambito internacional, compotta uma dificuldade no sentido de compreender as vátlas définiçöes já existentes, devendo ser "lo suficientemente amplia para comprender las variadas situaciones necesitadas de tulela. "TONIOLLO, Javier Alberto. La protección internacional del consumidor: reflexiones desde la perspectiva del derecho internacional privado argentino. Revista de Direito do Mercosul, Buenos Aires/Porto Alegre, ano 2, 1. 6, dez. 1998, p. 95.

15 Neste sentido, veja defendendo que a distinçăo entre consumidor e comerciantes, na Internet, não taria sentido GUHLLEMARD, Sylvette, Le 'cyberconsommateur' est mort, vive I'adhérent, in foumal du Droit International, 1, 2004, p. 7-61. Em sentido contrário, trabalho orientado por António Marques dos Santos, de OLIVEIRA, Elsa Dias. A proteção dos consumidores nos contratos celebrados através da Internet. Almedina, Coimbra, 2002, p. 10 e seg. e MARQUES, Confiança, p. 303 e seg.

16. Ensinam JAYME, Erik e KOHLER, Europäisches Kollisionsrecht 2004: territoriale Erweiterung und methodische Rückgriffe, in IPRAX, p. 483 e seg, que as últimas diretivas européias trazem normas de DIP, e em especial o Princípio do Reconhecimento (Anerkennungsprinzip), que pode prejudicar a proteçảo da vítima de produtos defeituosos e os consumidores em geral, permitindo fraudes e fugas à lei normalmente indicada aplicável. Talvez dá́ a opçăo por estabelecer em lei quais as normas imperativas, como no Art. 29a da EGBGB, veja sobre este problema metodológico, MARQUES, Confiança, p. 371 e seg.

17 Veja a proposta de uma CIDIP de proteção do consumidor, in MARQUES, Confiança, p. 303 -467 , em especial p. 460 e seg.

: Assim concordam BENIAMIN, António Herman de V., Consumer Protection in Less-Developed Countries: The Latin American Experience, in RAMSAY, laian (Ed.), Consumer Law in the Global Economy, Asgate, Brookfield, USA, 1996, p. 50 e REICH, Norbert, Consumerism and citizenship in the Information SocietyThe case of eletronic contracting, in WHLHELSSON, Thomas (Ed.), Consumer Law in the Anformation Society, Kluwer, Law Internationa, Haia/Londres/Boston, 2001, p. 163 e seg. Veja MARQUES, Claudia Lima (Org.), Estudos sobre a proteção no Brasil e no Mercosul, Editora Livraria dos Advogados, Porto Alegre, 1994 e El Código brasileño de dé̂́nsa del consumidor y el Mercosur, in CHERS1, Carlos Alberto (Diretor), MercosurPerspectivas desde el derecho privado, Editorial Universidad, Buenos Aires, 1996, p. 199-226.

is A distinção entre consumidor-ativo (que se desloca de um país para outro) e consumidor-passivo (que recebe a informação, que contrata em seu país, sem deslocamento físico) é muito utilizada na Alemanha e será aqui seguida para facilitar a exposição. Veja, por todos, usando a expressăo JAYME, Erik e KOHLER, Christian, Europäisches Kollisionsrecht 1999- Die Abendstunde der Staatsverträge, in IPRAX 1999, p. 404.

20 Assim BENIAMIN, Antonio Herman dę V., O transporte aéreo e o Código de Defesa do consumidor, in Revista AJURIS-Edição Especial, matço 1998, vol. II, p. 499 e seg. Veja também MARQUES, Claudia Lima, A responsabilidade do transportador áereo pelo fato do serviço e o Código de Defesa do Consumidor Antinomia entre norma do CDC e de leis especiais, in Revista Direito do Consumidor, São Paulo, vol, 3 (1992), pg. 155-197. 
O fenômeno do consumidor-passivo internacional e o do consumidorativo internacional já chegou aos países da América Latina ${ }^{24}$ e ao Brasil. ${ }^{22}$ Consumir de forma internacional é típico de nossa época. ${ }^{23} \mathrm{O}$ serviço ou produto estrangeiro é status, é bem simbólico na atual cultura de consumo; ${ }^{24} \mathrm{O}$ turismo, as viagens, o ser consumidor-ativo de forma internacional faz parte da procura pós-moderna ${ }^{25}$ dos prazeres, do lazer individual, da realização dos sonhos e do imaginário, é uma distinçāo social cada vez mais importante. ${ }^{26}$

Se o direito do consumidor tem vocaçāo internacional, ${ }^{27} \mathrm{em}$ tempos pós-modernos de forte globalizaçāo ${ }^{28}$ e utilização do mundo virtual, conclui-

2: Veja sobre a universalidade do ienomeno, KRONKE, Herbert, Applicable Law in Torts and Contracts in Cyberspace, in internet- Which Court Decides? Which Law Applies, in Boele-Woelki, Katharina e Kessedjian, Catherine (Ed), Kluwer Law International, Haia, 1998, p. 82 e seg.

22. Veja a proposta de uma CIDIP de proteção do consumidor, in MARQUES, Confiança, p. 360. Propỏe-se a seguinte definição de consumidor para o comércio inter-americano: "Proposta de Convenção CIDIP, I Regras Gerais, artigo $1^{\circ}$. Definição de Consumidor: 1 . Consumidor para efeitos desta Convenção é qualquer pessoa física que, frente a um profissional e nas transaçoes, contratos e situações abrangidas por esta Convenção, atue com fins que não pertençam ao âmbito de sua atividade profissional. 2 . Consideram-se consumidores também os terceiros pertencentes à família do consumidor principal ou os acompanhantes outros, que usufrutam diretamente dos serviços e produtos contratados, nos contratos abrangidos por esta Convenção, como destinatários finais destes. 3. Para o caso de contratos de viagens e de multipropriedade, considerar-se-á consumidores: a) o contratante principal ou pessoa física que compra ou se compromete a comprar o pacote turístico, a viagem ou time-sharing para o seu uso próprio; b) os beneficiários ou pessoas terceiras em nome das quais compra ou se compromete o contratante principal a comprar a viagem ou o pacote turístico e os que usufruem da viagem ou da multipropriedade por algum espaço de tempo, mesmo não sendo contratantes principais; c) o cessionário ou pessoa física aos quais o contratante principal ou beneficiário cede a viagem ou pacote turstico ou os direitos de uso. 4. Se a lei indicada aplicável por esta Convençào definir de forma mais ampla ou benéfica quem deve ser considerado consumidor ou equiparar outros agentes a consumidores, o juiz competente pode ter em conta esta extensăo do campo de aplicação da Convenção, se for mais favorável aos interesses do consumidor." Também in MARQUES, Cláudia Lima. A proteção do consumidor: aspectos de direito privado regional e geral. 纤 COMITÉ JURIDICO INTERAMERICANO. XXVII Curso de direito internacional privado da OEA. Washington: Secretaria Geral, $2001, p .763$.

23 Veja neste sentido, FEATHERSTONE, Mike, Cultura de Consumo e pós-modernismo, Frad. Júlio Assis Simöes, Studio Nobel, São Paulo, 1995, p. 31.

24 Aqui estamos seguindo os ensinamentos de FEATHERSTONE, p. 31 e seg.

25 Veja sobre rélexos da pós-modemidade no DIP, JAYME, Erik, Identité culturelle et intégration: Le droit international privé postmoderne, Recuell des Cours, tome 251 (1995), The Hague/Boston/London: Martinus Nijhoff Publ., 1996, p. 36 e seg.

26 Assim FEATHERSTONE, p. 31.

27 Veja BOURGOIGNIE, Thierry, Eléments pour une théorie du droit de la consommation, CDC-Story Sciencia, Bruxelas, 1988, p. 21555.

28 Veja sobre o tema, PERIN, Ecio Júnior, A Globalização e o Direito do Consumidor - Aspectos relevantes sobre a harmonização legislativa dentro dos mercados regionais, Ed. Manoela: Baueri, 2003, p. 45 e seg. Definindo globalizaçăo, CASTELLS, Manuel, End of Millennium (The Information Age: Economy, Society and culture, volume III), Blackwell P., Oxford, 1998, p. 1: "..this is indeed a time of change... a technological revolution, centered around information, has transformed the way we think, we produce, we consume, we trade, we manage, we communicate, we live, we die, we make war, and we make love. A dynamic global economy has been constituted around the planet, linking up valuable people and activities from all over world, while switching off from the networks of power and wealth, people and territories dubbed as irrelevant from the perspective of dominant interesis..." 
se mesmo pela insuficiência da proteção nacional e do DIP clássico, ${ }^{29}$ prevendose a necessidade de uma aproximação funcional, que uma normas clássicas de conflito e normas materiais, ${ }^{30} \mathrm{O}$ consumidor não deve ser prejudicado, seja sob o plano da segurança, da qualidade, da garantia ou do acesso à justiça somente porque adquire produto ou utiliza serviço proveniente de um outro pais ou fornecido por empresa com sede no exterior. ${ }^{31}$ A pergunta é como a jurisprudência brasileira está respondendo a esta internacionalização das relações de consumo, ${ }^{32}$ uma vez que nossas leis raramente possuem normas de direito internacional privado especiais para a tutela efetiva dos contratantes mais fracos, os consumidores domiciliados em nosso território. A solução é muitas vezes aplicar diretamente a norma nacional material de proteção e menosprezar o método conflitual clássico do DIP.

São as chamadas "leis de aplicação imediata", leis básicas de segurança do mercado ou sociedade ("sauvegarde de l'organisation politique, sociale ou économique du pays"), ${ }^{33}$ leis para nacionais e estrangeiros e para todas as relaçōes privadas, sem necessidade de antes passarem pelo método clássico do Direito Internacional Privado, da indicação de uma lei aplicável. Esta própria lei "de aplicação imediata" ou lei de "polícia" tem pretensões de aplicação genérica e extraterritorial sempre, não importando se são leis de direito privado, uma vez que positivam fortes interesses de organização da sociedade nacional. Como a chamada lei de aplicação imediata é direta ou resolve o conflito

29 Assim MARQUES, Confiança..., p. 329 e seg. , com base nos ensinamentos de Erik Jayme, Neuhaus, Jan Kropholler, Fausto Pocar, Pierre Mayer e Boggiano (BOGGIANO, Antonio, The Contribution of the Hague Conference to the Development of Private Intemational Law in Latin America. Universality and genius loci, in Recueil des Cours, 1992, II, t. 233, Nijhoff, Dordrecht, 1993, p. 138 e 139), dentre outros. Assim CALLESS, GralifPeter, Transnationales Verbrauchervertragsrecht, in RabelsZ 68 (2004), p. 249 e seg.

Assim nos manifestamos no artigo, Regulamento Comum de Defesa do Consumidor do Mercosul - Primeiras observações sobre o Mercosul como legislador da proteção do consumidor, publicado in Revista Direito do Consumidor, vol. 23-24, p. 79 e também, no mesmo sentido no Mercosul, STIGLIYZ, Gabriel, El derecho del consumidor en Argentina y en el Mercosur, in Derecho del Consumidor, vol. 6, 1995, p. 20.

32 Sobre a resposta da doutrina veja as obras de PERIN, p. Xll e 1 e seg. e FELLOUS, Beyla Esther. Proteçäo do consumidor no Mercosul e na União Européia, Săo Paulo: RT, 2003.

33. Na definiçăo classica de Franceskakis, reproduzida por BUCHER, Andreas, L'ordre public et le but social de lois en droit intemational privé, Recueil des Cours, 1993, 11, t. 239, Nijhoff, Dordrecht, 1994, p. 39, são leis ou regras "don't l'observation est nécessaire pour la sauvegarde de l'organisation politique, sociale ou économique du pays.", veja Art. 7, alinea 2 da Convenção de Roma da UE sobre lei aplicável às obrigaçỏes contratuais de 1980. Tais nomas se aplicam diretamente. Veja sobre o Art. 18 Lei de Dir. Internacional Privado suíça, BUCHER, p. 39. 
diretamente, sua aceitação e identificação hierárquica dentro do DIP é uma técnica (por sinal cada vez mais usada) de "materialização" das novas regras de conflitos de leis. ${ }^{34}$

Nesse artigo, queremos analisar justamente esta materialização do DIP brasileiro (Parte 1), assim como ressaltar a influência desse método na solução de questões envolvendo o direito do consumidor (Parte II). Nosso ponto de partida é a pergunta, face aos recentes desenvolvimentos no direito comunitário europeu e na Lei de Introdução ao Código Civil alemão (EGBGB), se a tendência de considerar as normas materiais de proteção do consumidor nacionais, como o CDC, pela jurisprudência brasileira, e as Diretivas européias, na legislação de DIP alemã, podem ser comparáveis como fases semelhantes de desenvolvimento de um DIP de proteção dos consumidores.

Desde 2001, Erik Jayme e Christian Kohler alertam para a mudança metodológica no DIP, que significa o novo Princípio do Reconhecimento imperativo de sentenças européias (Annerkungsprinzip), impondo uma espécie de ordem pública européia negativa, a impossibilitar praticamente que uma sentença de um membro da Comunidade viola-se a ordem pública de um outro Estado membro e não fosse reconhecida. ${ }^{35}$ Como não existem muitas normas de DIP de origem européia, mas sim muitas normas materiais (em especial na proteção dos consumidores), não tardou muito para que os especialistas de DIP ${ }^{36}$ identificassem ai também uma mudança metodológica, uma nova espécie de legislação indireta de DIP, por exemplo, através das Diretivas européias de proteção dos consumidores que expressamente afirmavam não conter nenhuma norma de DIP, mas que reflexamente eram imperativas e auto-limitavam seu campo de aplicação, como um standard mínimo ou ordem pública de proteção europeu.

Esta técnica não passou desapercebida do legislador alemão, que não contente em ter uma norma especial de DIP para contratos internacionais concluídos por consumidores (Art. 29 da EGBGB) resolveu criar um novo Artigo 29 a da EGBGB, dispondo que caso as normas materiais européias não fossem as indicadas pelas normas de conflito de leis (isto é, a contrario, se indicado

34 Segundo Erik Jayme (JAYME, Recueil, p. 44), uma das tendências do direito internacional privado pósmodemo ou atual seria a materialização das regras de conflito de leis e aplicaçăo reiterada da lex fori. Após a chamada "American revolution", movimento doutrinário e jurisprudencial ocorrido nos Estados Unidos na década de 1960, que repensou o método e a idéla de justiça no direito internacional privado, as regras de conflito de leis teriam superado seu automatismo e simples posiçăo instrumental de indicaçăo de uma lei material para resolver "diretamente" o conflito, passando agora a se interessar pela soluçāo concreta ou direta (material) do caso.

35 Jayme, Erik e Kohler, Christian, Europäisches Kollisionsrecht 2001: Anerkenungsprinzip statt IPR?, in IPRAX 2001, p. 501 e seg.

36 Assim manifestid-se, citando Jayme/Kohter, LAGARDE, RabelZ 68 (2004), p. 229 e seg, se bem que analisando casos de direito de familia e sucessôes. 
aplicável ou escothido fosse um direito de país terceiro), as Diretivas protetivas do consumidor se aplicariam de qualquer forma, como imperativas (veja art. 29a $\mathrm{EGBGB}) .{ }^{37}$

Em resumo, tais normas materiais sempre encontram aplicação, ou pelo método conflitual, quando a norma de DIP indica a lei de um país membro que as incorporou, ou -se a lei aplicável é de país terceiro- por força do Art. 29a do EGBGB, em uma espécie de novas normas imperativas de proteção dos consumidores, sempre cumulativas à indicação da lei aplicável. Já a norma francesa, parece preferir tratar a Diretiva como norma de ordem pública (sui generis) e afastar a lei indicada de terceiro país, se menos protetiva que a ordem pública (positiva) européia representada pela Diretiva. ${ }^{38}$ Aqui nos interessa mais a solução alemã do Art. 29a do EGBGB. Vejamos agora se o caso brasileiro é semelhante, pois em ambos os casos chegamos à aplicação material das normas nacionais materiais de proteção dos consumidores, seja por indicação do DIP, seja antes do recurso ao DIP.

37 Texto original em alemăo, livremente traduzido, publicado in IPRAX 1999, p. [304] VIt e in BGBL. Teil I N. $28 / 29$, Juni 2000, p. 901 , deste artigo é: "Art. 29 a EGBCB. (1) Se a lei escolhida para regular um contraio não é de um Estado Membro da UE ou do Espaço Econômico Eưopeu, são também aplicáveis as normas das leis que incorporaram Diretivas de proteçāo dos consumidores (L. Leis de proteçăo do consumidor sobre Condiçóes Gerais Contratuais, a Lei de Contratos à Distância e de Time-sharing), quando o contrato tenha um vínculo estreito com um ou mais países da União Européia (EU) ou do Espaço Econômico Europeu (EEE); (2) Un vínculo estreito existe quando: (1) O contrato seja feito em virtude de uma oferta pública, publicidade ou atos negociais semelhantes realizados em um dos Estados da UE ou EEE. (2). A outra parte contratante, quando declarou a sua vontade ou aceitou a oferta, tenha domicilio nos países da UE OU EEE. (3) A lei sobre time-sharing é aplicável ao contrató, regido por uma lei de um país não membro da UE ou EEE, quando o imóvel localize-se em um Estado da UE ou EEE. (4) Diretivas de proteção do consumidor no sentido deste artigo são: 1 . Diretiva 93/13/CEE, sobre cláusulas abusivas; 2 . Diretiva 94/47/CEE, sobre time-sharing 3. Diretiva $97 / 7 / \mathrm{CE}$, sobre contratos à distáncia."

38 A França introduziu no seu Código de consumo uma regra de DIP tornando imperativa a proteçấo de pelo menos uma das diretivas europélas. A regra do Code de la Consommation é o art. 1. 121-20-6, com a seguinte redação: "Lorsque les parties ont choisi la loi d'un État non membre de la Communauté européenne pour régir le contrat, le juge devant lequel est invoquée cette loi est' tenu d'en écarter l'application au profit des dispositions plus protectrices de la lol de la résidence habituelle du consommateur assurant la transposition de la directive $97 / 7 / \mathrm{CE}$ du Parlement européen et du Conseil du 20 mai 1997 concernant la protection des consommateurs en matière de contrats à distance, lorsque cette résidence est situé dans un Etat membre." 


\section{AS NORMAS DE APLICAÇÃO IMEDIATA EM MATÉRIA DE CONSUMO: UMA MATERIALIZAÇÃO DO DIP BRASILEIRO?}

Como vimos a globalização e a crescente industrialização acarretaram um incremento no tráfico comercial e social: a denominada massificação social e sociedade de consumo. ${ }^{39}$ As relações entre consumidores ${ }^{40}$ e fornecedores ${ }^{41}$ transformaram-se nas últimas décadas e, apresentam cada vez mais casos com elementos de estraneidade, ${ }^{42}$ casos próprios do Direito Internacional Privado. Aqui a importância de António Marques dos Santos, principalmente através de sua obra "As Normas de Aplicação Imediata no Direito Internacional Privado: Esboço de uma Teoria Geral", a renovar a análise dos métodos de direito internacional privado também no Brasil, procurando-se neste estudo analisar a efetividade dessas normas para a proteção internacional do consumidor vulnerável nestas situações privadas internacionais.

Conforme ressalta Nádia de Araújo, "a metodologia clássica do DIP inspirada nos moldes do século XIX -, mostra-se inadequada à complexidade $\mathrm{e}$ à diversidade do momento." ${ }^{43}$ Também na Europa, desde a década de 1970,

39 Veja GRINOVER, Ada Pellegrini; BENJAMIN, Antônio Herman de Vasconcellos. Introdução. In: GRINOVER, Ada Pellegrini et alli (orgs.). Código brasileiro de defesa do consumidor comentado pelos autores do anteprojeto. 4 ed., Rio de Janeiro: Forense Universitária, 1995, p. 6. Segundo os autores, "a sociedade de consumo, ao contrário do que se imagina, năo trouxe apenas benefícios para os seus atores. Multo ao revés, en certos casos, a posição de consumidor, dentro desse modelo, piorou em vez de melhorar. Se antes of fonecedor e consumidor encontravam-se em uma situaçăo de relativo equilibrio e poder de barganha (até porque se conheciam), agora é o fornecedor (fabricante, produtor, construtor, importador, ou comerciante) que, inegavelmente, assume a posição de força na relaçăo de consumo e que, por isso mesmo, 'dita as regras'. Eo direito năo pode ficar alheio a tal fenômeno."

40 Para um conceito de consumidor, veja MARQUES, Cláudia Lima. Contratos no Código de Defesa do Consumidor: o novo regime das relaçōes contratuais, 4 ed., São Paulo: Editora Revista dos Tribunâis, 2002, p. 252 et seq. O Código de Defesa do Consumidor brasileiro, Lei no 8.078 , de 11 de setembro de 1990 , define consumidor em seu artigo $2^{\circ}$ : "Consumidor é toda a pessoa física ou juridica que adquire ou utiliza produto ou serviço como destinatário final." Conforme refere Marques (p. 291), a vulnerabilidade é elemento essencial nesse conceito, inclusive para identificar os chamados consumidores equiparados do artigo $17 \mathrm{e}$ 29, estando expressamente disposta no artigo $4^{\circ}$, inciso 1. Veja também CHAZAL, Jean-Pascal. Vulnérabilité et droit de la consommation. In: COHET-CORDEY, Frédérique (org.). Vulnérabilité et droit: le développement de la vuinérabilité et ses enjeux en droit. Grenoble: Presses Universitaires, 2000, p. 243.

${ }^{41}$ Veja a análise do conceito em MARQUES, Contratos, p. 326 e seg.

42 Conforme Elmo Pilla Ribeiro: "esse dado ou elemento, que é um verdadeiro 'plus' a singularizá-la ou especializá-la em face das demais, pode ser a nacionalidade ou o domicílio da pessoa, o lugar da constítuição ou execução da obrigação, da situação de um bem, da verificação de um 'quasi-contrato', da prática de um ato ilícito, etc." RIBEIRO, Elmo Pilla. Contribuição ao estudo da norma de direito internacional privado. Porto Alegre: datilog., 1964, p. 12.

43 ARAÚO, Nadia. Direito internacional privado; teoria e prática brasileira. Rio de laneiro: Renovar, 2003 , p. 20. 
os doutrinadores propugnam a necessidade do Direito Internacional Privado voltar-se para a proteção dos mais fracos, especialmente dos consumidores, ${ }^{44}$ incluindo novos elementos de conexão mais flexíveis e adaptados à tutela do conexões "neutras" e rígidas, mais adaptáveis ao relacionamento entre iguais ou pelo menos entre profissionais, comerciantes, para a proteção dos consumidores novos métodos e normas de DIP seriam necessários. ${ }^{45}$ Aqui nos interessa a chamada "materialização" do DIP.

Até os estudos de Ernst Steindorff, em 1958, imaginava-se que a participação das normas materiais no direito internacional privado era um fenômeno "lateral", um fenômeno apenas "resultante" da indicaçāo (Verweisung) executada pela norma indireta de DIP. O DIP seria um direito de indicaçäo da lei aplicável (Verweisungsrecht ou Rechtsanwendungsrecht), não de decisão (Entscheidungsrecht). Steindorff comprovou que em inúmeras circunstâncias as normas materiais fazem parte integrante da técnica do DIP de solução do conflito de leis no espaço, ai sua grande contribuição. ${ }^{46}$

A mais conhecida utilização das normas materiais "dentro" do Direito Internacional Privado ou como parte integrante da técnica de DIP é na qualificação das questões principais e prévias, na interpretação dos elementos de conexão. Também destaca-se o uso de normas materiais no DIP, como auxiliares da solução "indireta" no caso da adaptação (Anpassung), quando é necessário aplicar uma série de normas materiais indicadas aplicáveis pelo DIP nacional ${ }^{47}$ e o aplicador da lei vai harmonizar, compatibilizar, adaptar estas normas materiais para poder usar no caso concreto.$^{48}$

Este uso de normas materiais de ajuda do DIP ficou conhecido com o nome alemão de Hilfsnormen, normas de ajuda da técnica normal do DIP. Este caso nos interessa menos, pois as normas materiais são usadas como auxiliares da técnica de regulamentação indireta, da indicação de um direito aplicável e não aplicadas diretamente ao caso "internacional privado". Dos estudos de Steindorff, mais interessante é um segundo grupo de normas materiais. Estas estariam no DIP, fariam parte da aplicação normal do sistema

44 Ficaram famosos os trabalhos de ZWEIGERT, NEUHAUS E LANDO, sugerindo o primeiro que o DIP incluíse valores sociais e, o segundo, que se abandonasse a autonomia de vontade nos contratos entre contratantes fracos e fortes, como os de consumo e o terceiro, pragmaticamente, que passasse o DIP a escolher como conexăo o domicilio do contratante mais fraco, veja também o estudo de VON HOFFMANN, Bernd von, Über den Schutz des Schächeren bei internationalen Schuldvertragen, in RabelsZ 38 (1974), (396-420), p. 398 e seg. e de KROPHOLLER, Jan, Das Kollisionstechtiche System des Schutzes der Schwächeren Vertragspartei, in RabelsZ 42 (1978), (634-661), p. 634 e seg.

45 Assim KROPHOLLER, 1978, p. 636.

46 STEINDORFF, Ernst, Sachnormen im internationalen Privatrecht, Vittorio Klostermann, Frankfurt am Main, 1958, p. 18.

47 VALLADÃO, Haroldo, Direito Internacional Privado, vol. l, Ed. Freitas Bastos, Rio de Janeiro, 1974,p. 462.

48 STEINDORFF, p.26. 
de Direito Internacional Privado, mas seriam normas materiais diretamente aplicáveis aos casos concretos. ${ }^{49}$ Estas normas materiais "especiais" realizariam a função das normas de DIP, isto, estariam no lugar das normas de indicação da lei. Estas normas materiais especiais aplicam-se aos casos com elementos de estraneidade, aplicam-se até mesmo extra-territorialmente, ao "nacionalizar" casos que seriam objeto de regras indiretas tradicionais de DIP. Estas normas materiais são uma solução especial, uma solução direta ao casos com elementos internacionais ${ }^{50}$ e seu exemplo mais conhecido na América Latina é o da norma interna (material) sobre o curso obrigatório da moeda nacional, norma que normalmente proibia a contratação de pagamento em dólar, mas permitia expressamente o uso destas cláusulas em contratos internacionais.

As mais famosas destas "normas" materiais, destinadas a regular diretamente casos envolvendo elementos internacionais, tiveram sua origem na jurisprudência francesa, em que os tribunais criaram a possibilidade de admissão das cláusulas-ouro nos contratos internacionais e de cláusulas sobre a arbitragem comercial intemacional. ${ }^{51}$ Aplicando-se as leis então indicadas pelo DIP ao caso concreto chegariam os juízes franceses à conclusão que tais cláusulas, que indexavam ou que permitiam o pagamento dos contratos internacionais em ouro, seriam nulas, mas a jurisprudência francesa resolveu o caso afirmando existir uma norma geral material interna francesa, a qual permitia a cláusula-ouro se o caso fosse internacional privado, isto é um contrato internacional. É uma norma interna, nacional, mas destinada a regular casos internacionais. Ela resolve diretamente o problema: a cláusula é válida. A norma material especial para casos internacionais assume a função do DIP, e faz parte do Direito internacional privado atual.

Para Marques dos Santos estas normas, sejam de origem jurisprudencial ou legislativa, deveriam ser consideradas autênticas "normas de aplicação imediata", logo, incluídas na técnica. ${ }^{52}$ A opinião do mestre português pode ser seguida se dermos a expressão "normas de aplicação imediata" uma conotação de gênero, o qual incluiria todas as exceções ao uso do método clássico "localizador" ou "de conexão" do Direito Internacional Privado.

\section{A TERMINOLOGIA "NORMAS DE APLICAÇÃO IMEDIATA"}

Como ressalta António Marques dos Santos, foi Francescakis, em sua obra La théorie du renvoi et les conflits de systèmes en droit international

\footnotetext{
49 STEINDORFF, p. 30.

50 STEINDORFF, P. 261.

51 MARQUES DOS SANTOS, p. 619.

32. MARQUES DOS SANTOS, p. 649 e p. 661.
} 
privé, ${ }^{53}$ de 1958 , que interpretando esta norma francesa, introduziu no âmbito do direito internacional privado a hoje consagrada expressão "lois d'application immédiate" ou normas de aplicação imediata, em português. ${ }^{54}$

Alguns anos mais tarde, em 1966, Francescakis afirmou, em seu artigo Quelques précisions sur les "lois d'application immédiate" et leurs rapports avec les règles de conflits de lois", que não teria se proposto à criação de um neologismo, ${ }^{5.5}$ aludindo que as raízes da construçāo do método advêm desde Savigny. ${ }^{36}$

As normas de aplicação imediata, segundo Francescakis, obstruiriam o funcionamento da regra de conflito e entrariam em cena toda vez que estivesse em jogo a defesa da organizaçăo estatal. ${ }^{57} \mathrm{O}$ autor partiu do exame de como os tribunais franceses aplicavam alguns dispositivos imediatamente, sem a intervenção das normas de conflito, ${ }^{58} \mathrm{com}$ base na noção de ordem pública, ${ }^{59}$ como "lois de police et surete" ou "lois d'ordre public", ${ }^{60} \mathrm{com}$ referência ao mencionado artigo do Code Civil francês. ${ }^{61}$ Sendo assim, identificou as leis de aplicação imediata como as que definiam seu próprio campo de aplicação. ${ }^{62}$

5.3 FRANCESCAKIS, Ph, La théorie du renvoi et les conflits de systèmes en droit international privé. Paris: Sirey, 1958, p. 8 .

5. MARQUES DOS SANTOS, António. As normas de aplicação imediata no direito internacional privado; esboço de uma teoria geral, Coimbra: Almedina, 1991, p. 2.

55 FRANCESCAKIS, Ph. Quelques précisions sur les lois d'application immédiate et leurs rapports avec les règles de conflits de lois. Revue Critique de Droit International Privé, Paris, n, 1, p. 1-18, 1966, p. 1.

56 Savigny salientava a existência de leis "absolutas ou rigorosamente obrigatórias", que se justificariam em razão de motivos motais, políticos e economicos em jogo. Segundo o autor, essas leis se revestiam de caráter político, de polícia ou de economia política e, para descobrir se determinada lei se inseria nesses casos excepcionais, dever-se-ia pesquisar a intenção do legislador. Assim, se fosse confirmado alguns desses casos, aplicat-se-ia, obrigatoriamente, a lei do foro. Deve ser salientado que Savigny não defendia a unicidade do método conflitual, referindo-se à existência de duas maneiras de solucionar os casos conectados a mais de ur ordenamento jurídico: a idéia de que poder-se-ia partir tanto da análise da regra e verificar seu âmbito de aplicação, quanto da análise da própria relaçâo, manifestando uma preferência pelo segundo método. As leis rigotosamente obrigatórias excluiriam, no entanto, qualquer utilização do método confítual bilateral. SAVIGNY, Frederich Carl Von. Traité de droit romain. Trad.: GUENOUX, Ch. Paris: Firmin Didot Frères Libraires, 1851, t. VII, p. 38.

FRANCESCAKIS, Quelques, p. 13.

FRANCESCAKIS, La théorie, p. 12.

Assim salienta o autor: "La jurisprudence dont il est question ici se fait du concept de l'ordre public international une idée toute différente. Elle estime que les dispositions internes présentant ce caractère s'appliquent comme telles immédiatement à toute les situations considérees au regard du droit français." FRANCESCAKIS, La théorie, p. 13.

60 O jurista verificou que a exceção da ordem pública nầo era utilizada pelos tribunais, preferindo, estes, aplicar diretamente a lex fori apenás com base na noçäo de ordem pública. Veja MARQUES DOS SANTOS, As normas, p. 8.

Gi FRANCESCAKIS, Quelques, p. 3.

62 FRANCESCAKIS, Quelques, p. 10. 
Segundo ensina Marques dos Santos, ${ }_{1}^{63}$ o mérito de Francescakis está em ressaltar a relativização do método conflitual, ${ }^{64}$ em sua concepção clássica, introduzindo, na expressão "leis de aplicação imediata", uma nova forma de solucionar as situaçōes de Direito Internacional Privado.

A questão por trás dessa aplicabilidade imperativa de determinadas leis está na constatação de que algumas normas se sobrepōem em razão do seu conteúdo normativo. ${ }^{65} \mathrm{Na}$ expressão de Savigny, são normas de natureza imperativa e positiva estrita (Cesetze von streng positiver, zwingender Natur). ${ }^{66}$

A expressão francesa, "lois d'application immédiate", usada por Francescakis desde 1958, popularizou-se, ${ }^{67}$ apesar de um estudo muito semelhante do italiano De Nova, que as denominava "norme sostanziali autolimitate" ou "norme di applicazione necessaria", datar de 1959. A segunda expressão francesa, "lois de police" ou leis de polícia, também ficou mais conhecida do que a expressão alemā, a significar leis obrigatórias, "zwingende Normen" (expressão de Savigny) ${ }^{68}$. Mencione-se que muitos incluem como técnica de regulamentação direta no DIP a elaboração de leis "imperativas" e leis de ordem pública internacional. ${ }^{69}$

Efetivamente, o fenômeno das leis de aplicação imediata pode ser distingüido das normas materiais especiais ("materielles Sonderrecht"), pois nas leis de aplicação imediata as suas normas materiais não são "especiais" para uso internacional, ao contrário, as leis e normas de aplicação imediata por sua importância na organização da sociedade nacional, são justamente as mesmas para a aplicação interna e internacional, visam uma aplicação para todos e para todas as relaçōes, a expandir seu campo de aplicação. ${ }^{70}$

63 Santos refere que Francescakis "teve a importancia radical de uma descoberta juridica fundamental, que garante ao seu autor um lugar na história da evoluçảo das doutrinas do DIP." MARQUES DOS SANTOS, As normas, p. 10.

6. Veja MOURA RAMOS, Rui Manuel Gens de. Droit international privé vers la fin du vingtième siècle: avancement ou recul? XV Congres5o Internacional de Direito Comparado. Separata do Boletim de Documentaçăo e Direito Comparado, n. duplo 73/74, Suplemento do Boletim do Ministério da Justiça, p. 85-125, 1998, p. 93-5. Veja também ARAUIO, Nádia de. O direito internacional privado e a proteção da pessoa humana: evoluçäo do método conflitual e a observância dos direitos fundamentais, In: COMITÉ JURIDICO INTERAMERICANO DA OEA. XXVII Curso de Direito Internacional Privado. Washington: Secretaria Geral, 2002 , p. 461-547, p. 490.

65 FRANCESCAKIS, Quelques, p. 3.

65 SAVIGNY, tome 8, p. 35, na traduçào francesa: "Lois d'une nature positive rigoureusement obligatoire, par là même n'admettant pas cette liberté d'appréciation qui n'a pas égard aux limites des divers États." Veja expressăo em alemăo, in Rechstainer, p. 13.

67 Assim SCHWANDER, Ivo, Lois d'application immédiate, Sonderanknüpfung, IPR-Sachnormen und andere Ausnahmen von der gewöhnlichen Anknüpfung im internationalen Privatrecht, Schulthess, Zurique, 1975, p. 184.

6B Assim SCHWANDER, P. 132.

69 SCHWANDER, p. 184.

70 KROPHOLLE, Jan, Internationales Privatrecht, Mohr Verlag, Tubingen, 1990, p. 80. 
Já Gerhard Kegel, relembra que nestes dois casos estamos diante de normas materiais sem dúvida "especiais", pois são normas diretas (materiais) usadas em casos de DIP, normas que pela sua formulação especial e por seu campo de aplicação ampliado solucionam diretamente as questões de uma situação da vida com elementos de estraneidade. Ambos os fenômenos são,pois, exceções ao uso do método conflitual tradicional do DIP e sua grande diferença não é entre si e sim entre estas normas materiais de uso nos casos de DIP e as normas materiais normais, cujo campo de aplicação ou aplicação às relações da vida privada só é dada justamente pelo próprio Direito Internacional Privado, que usando o método conflitual as indica aplicáveis ao caso concreto ou não. ${ }^{71}$

Conforme assevera Marques dos Santos, a expressão normas de aplicação imediata abrangeria três categorias: "as leis que não necessitam qualquer regulamentação para serem aplicadas (self executing statues); as leis que se aplicam a situações jurídicas nascidas anteriormente à sua entrada em vigor (acepção temporal): as leis que se aplicam no espaço independentemente do sistema geral de normas de conflitos de leis (acepção espacial)" ${ }^{\prime 2}{ }^{72}$ Eustamente, nessa última categoria, que se apresentam as normas de aplicação imediata no direito internacional privado, como independentes do método conflitual. ${ }^{73} \mathrm{E}$ a pluralidade de métodos em DIP.

\section{NORMAS DE APLICAÇÃO IMEDIATA, MATERIALIZAÇÃO E PLURALIDADE DE MÉTODOS EM DIP}

Na magnífica obra de Savigny, observa-se já menção à pluralidade de métodos e de normas de DIP, em seus comentários do Direito Romano, o qual determinava: (1) ora a aplicação do direito local (lex fori) ${ }^{74}$ (2) ora a aplicação das normas imperativas obrigatórias, ${ }^{75}$ (3) ora a aplicação da lei da sede da relação (ou, na visão atual, da lei mais conectada com a relação atípica), ${ }^{76}{ }^{(4)}$ ora, na maioria dos casos, a aplicação das regras materiais do jus gentium, um direito especial misto para as relações com elementos de estraneidade ou internacionais. ${ }^{77}$ Efetivamente, se na modernidade o método conflitual foi o

\footnotetext{
7 KEGEL, Gerhard. Internationales Privatrecht, 6.Aufl., Becck, Munique, 1987, p. 35.

72 MARQUES DOS SANTOS, As normas, p. 2.

/3 FRANCESCAKIS, Quelques, p. 4. Veja, no Brasil, a obra de BOUCAUIT, Carlos Eduardo de Abreu, Direitos Adquiridos no Direito Internacional Privado. Porto Alegre: Fabris Ed., 1996, p. 65 e seg., assim como a liçăo sobre competência de PONTES DE MIRANDA, Francisco C. Tratado de Direito internacional Privado, tomo I, Rio de Janeiro: José Óympio, 1935, p. 186 e p. 241, assim como o ámplo levantamento realizado por VIEIRA VILELA, Danilo. As normas de aplicação imediata no Direito Internacional Privado, Disss. de Mestrado-Mimeo, UNESP, Franca-SP, 2003, p. $92 \mathrm{e} \mathrm{seg.}$

SAVIGNY, p. 35.

SAVIGNY, p. 80.

77 SAVIGNY, p. 84.
} 
método principal do DIP, ${ }^{78}$ e as normas indiretas serviram para construir a autonomia desta disciplina, ${ }^{79}$ na pós-modernidade, Erik Jayme chama atenção para a atual materialização do DIP, agora voltado para o resultado (material) do caso e para a proteção dos mais fracos. ${ }^{80} \mathrm{Em}$ tempos pós-modernos, a pluralidade de métodos e de normas indiretas e diretas faz a riqueza do novo DIP.

Para Moura Ramos, a tendência se refere à passagem do direito intemacional privado do âmbito reservado e abstrato para o domínio do social e do público, ${ }^{81}$ em que esse ramo jurídico "passa a ser também responsabilizado - e agora não apenas por via de excepção como sucedia com a ordem pública internacional - pela promoção dos valores que a comunidade sente como seus $(\ldots)^{\prime \prime}{ }^{82}$ Essa passagem ocorre, principalmente, ante o intervencionismo do Estado e, por isso, as normas de aplicação imediata nāo podem ser afastadas do contexto histórico em que se inscreveram. ${ }^{83}$ Relembre-se, porém, que no Brasil, não há unanimidade na doutrina, se o DIP é um ramo do Direito Privado, se é ramo do Direito Público ou um terceiro gênero. ${ }^{84}$ Talvez por isso autores brasileiros prefiram estudar a ordem pública, no seu aspecto positivo e negativo, no Direito Internacional Privado. ${ }^{85}$

Efetivamente, tratam-se de normas que fixam seu próprio campo de aplicação em razão dos valores jurídicos a que visam proteger, ${ }^{86}$ equiparando a relação internacional a uma relação interna, ${ }^{87}$ na medida em que correspondem a normas materiais, muitas vezes formuladas para reger determinadas situações do âmbito do

78 Veja, por todos, KEGEL, Gerhard e SCHÜRIG Klaus, Internationales Privatrecht- Ein Studienbuch, 92 Ed., Munique: Beck, 2004, p. 4 e seg. (\$1, II).

79 Veja, por todos, no Brasil a obra de PILLA RIBEIRO, Elmo, Contribuição ao estudo da norma de Direito Internacional Privado, Porto Alegre: UFRGS, 1964, p. 11 e seg.

w J IAME, Erik, Identité culturelle et intégration : Le droit international privé postmoderne, Recueil cles Cours, tome 251 (1995), The Hague/Boston/London: Martinus Nijhoff Publ., 1996, p. 36 e seg.

B1 MOURA RAMOS, Rui Manuel Gens de. Direito internacional privado e constituição. Boletim da Faculdade de Direito, Suplemento XX. Coimbra, p. 267-526, 1973, p. 358 .

82 Segundo o autor, "O aparecimento das nomas de aplicaçāo inediata traduz uma publicização de uma disciplina até então reconhecida para os domínios puramente privados." MOURA RAMOS, Direito, p. 502. Conforme acentua RACINE, Jean-Baptiste. L'arbitrage commercial internacional et l'ordre public. Paris: LGDJ, 1992, p. 15, "le particularisme des lois de police est de révéler le mouvement d'iftervention de l'Etat dans la sphère économique." E citando Mezghani, aduz que "avec le développment de l'interventionnisme étatique, il arrive que la réalisation de la politique législative, en matière économique notamment, se conclie mal avec les incertitudes de la règfe de conflit de lois. Certaines lois sont nécessaires à la mise en oeuvre de cette politique."

84 Veja, por todos, VAlLADÄO, Haroldo, Direito Internacional Privado,t. I, Freitas Bastos : Rio de faneiro, 1974, p. 49-59: "A pergunta, pois, sobre a posição do DIP entre as ciencias jurídicas, se é internacional ou interno, se é público ou privado, so poderá ter esta resposta: o DIP tem normas de caráter internacional...e interno, de nátureza pública... e de caráter privado..."

35. Sobre a pluralidade de métodos do DIP, veja, por todos, a atualizada visăo de ARAÚJO, Nádia, Direito Internacional Privado, Rio de Janeiro: Renovar, 2003, p. 31 e seg.

BS MARQUES DOS SANTOS, As normas, p. 897 e ARAÚIO, Direito, p. 96.

87 LECIERC, Frédéric. La protection de la partie faible dans les contrats internationaux. Bruxelas: Brtlylant, 1995, p. 275. 
foro. As denominadas regras materiais (segundo a expressão alemã, Sachenrecht) (38 $^{38}$ ou substanciais ou mandatórias (segundo a expressão norte-americana, mandatory rules $^{89}$ fornecem solução direta aos casos jurídicos em contraposição às denominadas normas indiretas.$^{90}$ Conforme salienta Oppetit, são normas que enunciam diretamente a soluç̧ão aplicável à questão de fundo do litígio. ${ }^{9 !}$

O caráter material das normas de aplicação imediata está no fato de que elas solucionam diretamente a relação jurídica, ${ }^{92}$ não se confundindo, assim, com as normas de conflitos clássicas. ${ }^{93}$ Marques dos Santos refere que muitos autores, objetivando "desvalorizar a radical especificidade da técnica que elas (as normas de aplicação imediata) representam para o DIP dos nossos dias," procuraram negar essa característica, concebendo-as como parte do sistema conflitual. ${ }^{94}$ Para esses autores, não haveria regras de direito internacional privado material que pudessem ser aplicadas sem terem sido designadas por normas de conflitos. Segundo Moura Ramos, para essa corrente,

33. Veja VON BAR, Christian, Internationales Privatrecht, Erster Band-Allgemeinen Tell, Beck: Munique, 1987, 1, p. 25 (Rdn.32), que analisa també outros tipos de normas materiats de DIP, como o direito uniforme ("Einheitstecht staat Kollisisonsrecht"), a lex mercatoria e o besondere Sachenrecht.

89 AUDIT, Bernard, Le caractère fonctionnel de la règle de conflit (sur la "crise" des conflits de lois). In: Recueil des Cours de l'Académie de Droit International de la Haye, 1984, t. 186. The Hague/Boston/ London: Martinus Nijhoff Publishers, 1985, p. 255. Conforme acentua também Batiffol, "l'adjectif "matériel" s'entend pas opposition au caractère formel des règles de conflits; dans les pays de common law on parle plus généralement de substantive law, et l'expression de règles substantielles a paru longtemps plus claire en français." BATIFFOL, Henri. Le pluralisme des méthodes en droit international privé. Recueil des Cours de l'Académie de Droit International de la Haye, 1973, t. 139, Leiden: A.W. Sithoft, 1974, p. 82.

90 MIAIA DE LA MUELA, Adolfo. Las normas materiales de derecho internacional privado. Revista Española de Derecho Internacional, v. XVI, n. 3, 1963, p. 425. Segundo o autor (p. 425) as normas materiais estão "integradas por un supuesto corresponde, consistente en la atribucion de derechos subjetivos y en la imposición de obligaciones jurídicas a sus destinatarios."

91. OPPETIT, Bruno. Le développement des règles matérielles. COMITÉ FRANCAIS DE DROITINTERNATIONAL PRIVÉ. In: Journée du Cinquantenaire; problèmes actuels de méthode en droit international privé. Paris: Éditions du Centre National de la Recherche Scientifique, 1988, p. 122.

92 LECLERC, la protection, p. 330; SPERDUTI, Giuseppe. Les lois d'application récessaire en tant que lois d'ordre public. Revue Critique de Droit Interrational Privé, Paris, t. 66, p. 257-270, 1977, p. 671 e LALIVE, Pierre. Tendances et méthodes en droit international privé. Cours général. Recueil des Cours de I'Académie de Droit International de la Haye, 1977, 1. 155. Alphen aan den Rijn (The Netherlands): Sijhoff \& Voordhoff, 1979, p. 130.

93 No glossário de direito internacional privado, elaborado pelos autores Beliard, Riquier e Wang, no item lei de aplicação imediata, encontra-se referência ao conceito de Vander Elst: "(...) I'on peut dire que les lois d'application immédiate sont les lois de droit matériel qui, dans la volonté du législateur, doivent s'appliquer aux actes et aux faits qu'elles visent, quelle que soit la loi régit ces actes ou faits en vertu des règles de conflit des lois." BELIARD, Gérałdine; RIQUIER, Eric; WANG, Xiao-Yan. Glossaire de droit intemational privé. Bruxelas: Bruylant, 1992, p. 183. Veja também MARQUES DOS SANTOS, António. Les règles d'application immédiate dans le droit international portuguais. Paris: Fondation Calouste Gulbenkian, 1991, p. 181.

4: MARQUES DOS SANTOS, As normas, p. 816. O autor cita especificamente os juristas Maury e DebyGérard. Veja também MOURA RAMOS, Direito, p. 341, que, além dos já citados, refere-se a Rigaux, Brotons, Neuhaus e Ferrer Correia. Veja também sobre essa discussão, IECLERC, La protection, p. 280 . 
"o que estaria em causa com este novo processo não seria uma construção de uma alternativa ao DIP enquanto direito de conflitos, mas um mero aperfeiçoamento das ordens jurídicas intemas, uma sua especialização para os problemas internacionais." $95 \mathrm{Em}$ um primeiro momento, esse pensamento reduziria a importância das normas de aplicação imediata, na medida em que as colocaria dentro do sistema de conflitos de leis clássico, atingindo, portanto, sua autonomia enquanto método de direito internacional privado. ${ }^{96}$ Outra visão é possível. Nesse sentido, Batiffol sustentou a coexistência de ambos os métodos no direito internacional privado, ${ }^{97}$ salientando, com apoio de muitos, ${ }^{98}$ que se trata de categoria distinta. ${ }^{99}$

Neste contexto, importante a contribuição de António Marques dos Santos com um estudo aprofundado sobre o tema, defendendo a visão pluralista hoje prevalente do direito internacional privado, qual seja, a existência de um pluralismo de métodos. ${ }^{100}$ As normas de aplicação imediata consagrammse assim como método alternativo de soluçāo de casos de direito internacional privado. ${ }^{101}$

95 MOURA RAMOS, Direito, p. 342.

96 Moura Ramos cita Bauer, E. Vitta e Simon Depitre "que defendem, ainda que, em termos diversos, a autonomia e independencia das regras materiais face ao método conflitual, salientando que o Dip material aparece como um processo diferente, paralelo e não subordinado ao conflito de leis." lbidem, p. 342.

y7 BATIFFOL, Le pluralisme, p. 145.

93 LECLERC, La protection, p. 277; AUDIT, Le caractère, p. 23 e KARAQUILLO, Jean-Pierre. Étude de quelques manifestations de lois d'application immédiate dans la jurisprudence française de droit international privé. Paris: Press Universitaires de France, 1977, p. 15-17.

9 Assim tamberr Oppetit, ao afimar que "la notion de règle matérielle prend place aujourd'hui, à part entière, dans les fombreuses discussions qui, depuis une vingtaine d'années, ont eu pour axe central la méthode du droit international privé, et elle est même parfois apparue comme un élément de la crise des conflits de lois." OPPETIT, Le développement, p. 122.

100 MARQUES DOS SANTOS, As normas, p. 1068. Por essa razão, sustenta o autor, ser impossivel discorrer sobre as normas de aplicação imediata sem abordar toda a problemática metodologica do direito internacional privado. MARQUES DOS SANTOS, As normas, p. 1057.

:01 AUDIT, Le caractère, p. 255: "ll est à la rigueur légitime de parler de méthode des lois de police, dans la mesure où c'est par une analyse du but poursuivi par les lois, puis d'une confrontation de ces but's aux faits de l'espèce, que l'on se prononce sur l'application ou la non application de la loi." No mesmo sentido, MARQUES DOS SANTOS, As normas, p. 964: "As normas de aplicação imediata como método autônomo do DIP." Veja também MAYER, Pierre. L'interférance des lois de police. In: CHAMBRE DE COMMERCE INTERNATIONALE. L'apport de la jurisprudence arbitrale. Seminaire des 7 et 8 avril 1986. Paris: ICC Publishing, 1986, p. 34: "il existe donc une méthode des lois de police, qui s'oppose à la méthode classique du conflit de lois (...)". GUED,, Thomas G. The theory of the lois de police, a functional trend in continental private international law - a comparative anałysis with modern American theories. The American fournal of Comparative Law. V. 39, p. 661-697, 1991, p. 696: "1t has been contended in this article that the theory of the lois de police represent a functional trend in continental P.I.L. which thereby illustrates a Pluralism of methods". LECLERC, La protection, p. 277; KARAQULLLO, Étude, p. 20 e GOLDSTEIN, Gérald. De l'exception d'ordre public aux règles d'application nécessaire. Montreal: Thémis, 1996, p. 92. Sobre o pluralismo de métodos em direito internacional privado, veja BATIFFOL, Le pluralisme, p. 79 e IAYME, Recueil des Cours, 1995, t. 251, p. 39. 
A sua aplicabilidade está relacionada à capacidade de definir seu próprio âmbito de aplicação no espaço, ${ }^{102}$ tendo em conta os interesses a que visa proteger. Alguns autores, como Rigaux, ${ }^{103}$ Lalive, $^{104}$ Leclerc $^{105}$ e Marques dos Santos, ${ }^{106}$ embora reconheçam o caráter material da norma de aplicação imediata, salientam que ela é acompanhada de uma regra de conflito de lei unilateral.

Para Lalive a norma de aplicação imediata tem um caráter misto: é uma regra material na medida em que contém uma regulamentação substancial e é uma regra de conflito na medida em que se autolimita. ${ }^{10 \%}$ Por outro lado, salienta o autor que não há identidade entre as normas materiais autolimitadas ${ }^{108}$ e as regras de conflito de leis, sob pena de comprometer a independência teórica das normas de aplicação imediata. ${ }^{109}$ Leclerc se posiciona no mesmo sentido que Lalive, ao afirmar que as normas de aplicação imediata têm natureza mista e nāo escapam, portanto, do processo de conflito de leis. ${ }^{110}$ Para o autor, o seu caráter conflitual está na capacidade da norma de aplicação imediata fixar seu próprio campo de atuação no espaço. Em outras palavras, teriam dupla função, de direito de indicação da lei aplicável, Rechtsanwendungsrecht e também de direito de decisão, Entscheidungsrecht. ${ }^{11}$

Nesta linha, parece-nos, encontrar-se o pensamento de Marques dos Santos, para quem a norma de aplicação imediata tem caráter conflitual ou espacial, em sentido lato, ${ }^{112}$ uma vez que são providas de uma regra de extensão, que é na realidade, "uma regra de conflitos unilateral ad hoc, (...) a qual tem por função determinar, fora do sistema geral de regras de conflitos - maxime de caráter bilateral - o domínio de aplicação espacial da norma material (ou do

\$32 Assim estabelece também o glossário de direito internacional privado, "cette exclusion résulte de ce que la norme, outre son contenu matériel, délimite ellemême son champ d'application." BELIARD, RIQUIER E WANG, Glossaire, p. 183.

:03 Apud BELIARD, RIQUIER e WANG, Glossaire, p. 183: "C'est comme le dit Rigaux, une disposition de droit matériel qu'accompagne une régle de conflit de lois."

104 LALIVE, Tendances, p. 133.

ios LECLERC, La protection, p. 280.

106 MARQUES DOS SANTOS, As normas, p. 1063.

107 LALIVE, Tendances, p. 133.

108 Veja sobre as teorias italianas de auto-limitação de DENOVA, SCHWANDER, p. 132-184.

108 LALIVE, Tendances, p. 135: "L'impression générale qui se dégage de cet examen est celle d'une grande incertitude: ces règles matérielles autolimitées sont-elles ou ne sont-elles pas identiques à des règles unilatérales de rattachement?"

110 Nas patavras do autor: "En reatité les lois de police autait une nature mixte. Règles matérielles dans la mesture où elles contiennent une règlementation de substance, elles sont en même temps règles de conflit dans la mesure où elles établissent elles-mêmes quand elles doivent s'appliquer plutot qu'une règle étrangère matérielle. Les lois de police n'échapperaient donc pas fondamentalement au procédé du rattachement et ne jouiraient que d'un particularisme limité." LECLERC, La protection, p. 280.

$1: 3$ JUNKER, Abbo, Internationales Privatrecht, Murique: Beck, 1998, p. 15 (Rdn. 17).

12 MARQUES DOS SANTOS, As normas, p. 893. 
conjunto de normas materiais) à qual (ou ao qual) ela está incidivelmente ligada." "it3 Para Marques dos Santos tratam-se de normas de conflitos unilaterais ad hoc e podem ser designadas como "regras de acompanhamento", 114 sendo referidas apenas a uma singular norma material, ou a um conjunto de regras substantivas inseridas em um particular diploma legal. ${ }^{115}$

Assim, pode-se afirmar que o método das normas de aplicação imediata vem ao encontro de uma tendência unilateralista, ${ }^{116}$ uma vez que é a vontade de aplicação da norma que determina unilateralmente o seu campo de aplicação. ${ }^{17}$ As normas de aplicação imediata introduzem também uma revisão dos próprios fundamentos do direito internacional privado na dialética entre o unilateralismo e o bilateralismo e nas considerações sobre justiça material e conflitual. ${ }^{118} \mathrm{O}$ caráter conflitual unilateral a que se referem os autores está relacionado à capacidade de a norma de aplicação imediata fixar seu próprio campo de aplicação. ${ }^{119}$

Nesse sentido, a particularidade da norma de aplicação imediata está em não considerar os aspectos internacionais da situação jurídica e se fazer aplicar como se fosse uma relação jurídica interna. ${ }^{120}$ Trata-se, como afirma Libchaber, de transportar para a ordem internacional, a imperatividade de certas regras internas, ${ }^{121}$ em especial visando a proteção de certos valores e sujeitos vulneráveis. Não podemos esquecer aqui a força do Código de Bustamante. ${ }^{122}$

\footnotetext{
313 MARQUES DOS SANTOS, As normas, p. 890.

11: MARQUES DOS SANTOS, As normas, p. 890.

${ }^{11.5}$ MARQUES DOS SANTOS, As normas, p. 896-7. O autor, não obstante, refuta veemente qualquer tentativa de inserir as nomas de aplicaçào imediata de acordo com o viés conflitual clássico: "Quanto a nós, este tenaz preconceito "conflitualista" - tal como alguns que já tivemos o ensejo de analisar e outros mais com que ainda havemos de deparar, relativamente às regras de aplicaçảo necessárias estrangeiras - deve ser energicamente repudiado, pelo que, co contrário do que afimam alguns juristas que continuam a admitir essa posição, pensamos que o campo de aplicação máximo, bem como mínimo \{e não apenas este\}, das normas de aplicação imediata é sempre fixado, em completa e total autonomia, pela regra de extensảo ad hoc-que é, neste caso, como sel viu, uma verdadeira regra de conflitos unilateral, embora referida apenas a uma singular noma material, ou, quando muito, a um conjunto de regras substantivas inseridas num particular diploma legal, e năo uma simples noma delimitadora com caráter material - e nunca, em caso algum, pela norma de conflitos bilateral \{ou unilateral bilateralizada) do sistema geral do DIP da ordem juridica a que pertencem as normas materiais."
}

\$: Veja GOTHOT, Pierre. Le renouveau de la tendance unilatéraliste en droit international privé. Revue Critique de Droit Intemational Privé, Paris, n. 1, p. 1-36, 209-43, 415-50, 1971.

117 MARQUES DOS SANTOS, As normas, p. 1064.

118 Veja MOURA RAMOS, Droit, p. 93. Veja tambem VISCHER, F. The antagonism between legal security and the search for justice in the field of contracts. Recueil des Cours de l'Academie de Droit International de lat Haye, 1974, t. 142, Leiden: A. W. Sithoff, 1975, p. 30.

119 Para Santos, "a auto-ímitação espacial das normas de aplicaçăo imediata é extrúnseca à sua previsăo, tendo, por conseguinte, caráter conflitual ou espacial hoc sensu (..." $)^{\prime \prime}$ MARQUES DOS SANTOS, As normas, p. 939.

120 FRANCESCAKIS, La theorie, p. 14 e LECLERC, La protection, p. 275.

\$27 $\angle$ IBCHABER, Rémy. L'exception d'ordre public en droit international privé, fn: REVET, Thierry (org.). L'ordre public à la fin du XXe siècle, Paris: Dałloz, 1996, p. 70. No mesmo sentido, MARQUES, Contratos, p. 126.

122 Veja OCTAVIO, Rodrigo, A codificaçăo do Direito Internacional Privado, Ed. Francisco Alves e Cia., Rio de Janeiro, 1910, p. 7 e seg. ${ }^{23}$ KARAQUHLLO, Etude, p. 19 e 138. 
Saliente-se que o mecanismo das normas de aplicação imediata deveria ser utilizado excepcionalmente, ${ }^{123}$ sob pena de depreciar o próprio método. Assim, afirma Marques dos Santos que é "inaceitável a aplicação das normas de aplicação fora do âmbito de aplicação necessária - dentro do chamado campo de aplicação possível -, já que o teor e o fim da regra implicam um certo campo de aplicação espacial autónomo, e não qualquer outro, sob pena de desvirtuar a própria norma de aplicação imediata." 124

Mesmo com a pretensão de aplicabilidade restrita das normas de aplicação imediata, Belandro assinala que são as regras de conflitos que adquirem um caráter de subsidiariedade, uma vez que primeiro se verifica a existência daquelas normas para determinada situação jurídica e, só em caso negativo, proceder-se-á ao recurso das regras de conflito. ${ }^{125}$ Conforme ressalta Marques dos Santos, a sua aplicação excepcional está em consonância, destarte, com a sua prevalência sobre as regras de conflito, ${ }^{126}$ tendo em vista que os objetivos perseguidos pelas normas de aplicação imediata são de tal modo importante para a ordem jurídica do foro - em que elas se inserem - , que não podem deixar de ser perseguidos mediante o uso normals da norma de conflitos geral, remete a questão para uma lei estrangeira. ${ }^{127}$

A questão sobre se as normas de aplicação imediata reduzem o papel do método conflitual bilateral a um papel meramente residual ${ }^{128}$ é considerada, por Marques dos Santos ${ }^{129}$ e Pierre Mayer ${ }^{130}$ como uma questão meramente acadêmica ante a constatação do atual pluralismo de métodos afirmado no direito internacional privado. ${ }^{131}$ Assim, a importância das normas de aplicação está em representar um método autônomo ${ }^{132}$ de solução de casos do direito internacional privado, cuja aplicação é de extrema importância para o seu reconhecimento na ciência jurídica. ${ }^{133}$

124 MARQUES DOS SANTOS, As normas, p. 941.

${ }^{125}$ BELANDRO, Ruber B. Santos. Las nomas de aplicación inmediata en la doctrina y en el derecho positivo.

Revista de la Faculdad de Derecho, Montevidéu, n. 8, jul./dez. 1995, p. 41. Nas palavas do autor: "La regla indirecta no solo pierde así su pretensión a la plenitud como procedimiento de solucion en el derecho internacional privado sino que además adquiere una necessaria subsidiariedad debido a que sólo podrá actuar en el caso de inexistencia o un desinterés de las normas unilaterales."

13. MARQUES DOS SANTOS, As normas, p. 956.

¿27 MARQUES DOS SANTOS, As normas, p. 956.

:28 Conforme Batiffol, o sistema conflitual pode ser considerado subsidiário sob o ponto de vista cronológico, mas conserva ainda a sua generalidade de fundo. Veja BATIFFOL, Le pluralisme, p. 145.

129 MARQUES DOS SANTOS, As normas, p. 962-3.

:30 MAYER, PIerTe. Les lois de police. In: COMITÉ FRANCCAIS DE DROIT INTERNATIONAL PRIVÉ. JOUInée du Cinquantenaire; problèmes actueles de méthode en droit international privé. Paris: liditions du Centre National de la Recherche Scientifique, p. 105-120, 1988, p. 107: "Les objections que l'on a fait valoir à I'encontre d'une telle dérogation ont d'abord été de nature academique."

131 MAYER, Les Jois, p. 107; BATIFFOL, Le piuralisme, p. 82; AUDIT, Le caractère, p. 231; LECLERC, La protection, p. 277 e KARAQULLLO, Elude, p. 15-7.

\$32 MARQUES DOS SANTOS, As normas, p. 975 e FRANCESCAKIS, La theorie, p. 15: "L'existence de règleS d'application immédiate du droit interne doit par conséquent être reconnue à côte de règles de droit intemational privé, notamment à côte des règles de conflit." FRANCESCAKIS, Quelques, p. 17, em que o autor afirma à dualidade de métodos. MAYER, L'interférence, p. 34: "il existe donc une méthode des lois de police, qui s'oppose a la methode classique du conflit de lois"

i33 FRANCESCAKIS, Quelques, p. 3, o autor parte da análise da jurisprudencia francesa para afimar a existência de leits de aplicaçäo imediata. 
O rol das matérias que podem se apresentar como norma de aplicação imediata pode ser extenso. Citam-se: as normas de proteção à parte mais fraca, ${ }^{134}$ entre elas as normas de proteção do consumidor, ${ }^{135}$ relativas à proteção do patrimônio cultural, ${ }^{136}$ em matéria de direito do trabalho, ${ }^{137}$ proteção de menores, ${ }^{138}$ na representação comercial, ${ }^{139}$ no direito de família, ${ }^{140}$ entre outras. ${ }^{141}$ Assim, como ressalta Leclerc, certas leis, mesmo que nāo concorram para a proteção da organização do Estado, desde que seus fins sejam considerados necessários, podem ser caracterizadas como normas de aplicação imediata ${ }^{142}$ Trata-se, segundo Batiffol, de traduzir para o plano internacional a evolução das próprias instituições internas. ${ }^{143}$ Neste contexto, passa-se a análise do método das normas de aplicação imediata para a proteção do consumidor.

\section{A UTILIZAÇÃO DAS NORMAS DE APLICAÇÃO IMEDIATA PARA A PROTEÇÃO DO CONSUMIDOR BRASILEIRO}

A questão da proteção do consumidor em relações internacionais "pressupõe o diálogo entre o Direito do Consumidor e as normas (e princípios) do Direito Internacional Privado." ${ }^{144}$ Conforme anteriormente salientado, muitas

${ }^{334}$ LECLERC, La protection, p. 276. No mesmo sentido, MOURA RAMOS, Rui Manuel Gens de. La protection de la partie contractuelle la plus faible en droit international privé portuguais. In: . Das relaçōes privadas intemacionais; Estudos de direito internacional privado. Coimbra: Coimbra Editora, 1995, p. 200, en que afirma que "parmi ces valeurs, la protection des faibles occupe une place majeur. Considerée aujourd'hui à juste titre comme un des leit-motive du droit privé actuel"

135 MARQUES, A proteção, p. 675; ARAÚjO, Direito, p. 19; LECLERC, La protection, p. 98 e MARQUES DOS SANTOS, As normas, p. 902. Para Mayer e Heuzé, "les règles qui visent à ta prolection des consommateurs n'ont a'un but de protection individuelie; mais ce but n'en rend pas moins nécessaire feur application à tous les consommateurs fésidant sur le territoire, nonobstant la soumission du contrat, par la volonté des parties, à une loi étrangère moins protectrice." MAYER, Pierre e HEUZÉ, Vicent. Droit international privé, 7 ed., Paris: Montchrestien, 2001, p. 83-4.

136 MARQUES DOS SANTOS, As normas, p. 905.

137 MARQUES DOS SANTOS, As normas, p. 913 e LECLERC, La protection, p. 98.

138 LECLERC, La protection, p. 98.

:39 KARAQULLLO, Étude, p. 64.

140 KARAQULLLO, Étude, p. 58. O autor estuda a jurisprudência francesa em muitos campos do Direito onde observou o uso das nomas de aplicaçäo imediata.

14: Veja LECLERC, La protection, p. 98, em que menciona, ainda, a proteção do locatário, regras relativas às obrigaçöes alimentates, à regulamentação da concorrência, às cláusulas de indexação, etc.

142 LECLERC, La protection, p. 276-7.

i43 Apud LECLERC, La protection, p. 290.

:4s MARQUES, Contratos, p. 121. 
regras de defesa do consumidor, em razão dos objetivos a que visam resguardar, ${ }^{145}$ que identificam sua característica de proteção social e direção econômica, ${ }^{146}$ são consideradas normas de aplicação imediata. A sua imperatividade, observada no direito interno, passa, dessa forma, a regular relações próprias do direito internacional privado. ${ }^{147}$ Como Calais-Auloy e Steinmetz salientam a proteção do consumidor é organizada, essencialmente, para o plano nacional e, excepcionalmente, encontra aplicação em casos internacionais. ${ }^{148}$

\section{O Código de Defesa do Consumidor - Lei 8.078/90 como lei de aplicação imediata: a opinião da doutrina em matéria de comércio eletrônico}

No Brasil, foi editada a Lei $n^{\circ} 8.078$, de 11 de setembro de 1990, em vigor desde 11 de março de 1991, conhecida como Código de Defesa do Consumidor por denominação constitucional (Art. 48 dos Atos e Disposições transitórias da Constituição Federal brasileira de 1988), ${ }^{149}$ destinada a reger as relaçōes entre fornecedores e consumidores, estes protegidos por direito fundamental (Art. 5, XXXIl da Constituição Federal de 1988). O artigo $1^{\circ}$ do Código de Defesa do Consumidor (CDC) expressamente dispõe sobre o seu caráter imperativo: "Art. $1^{\circ} \mathrm{O}$ presente código estabelece normas de proteção e defesa do consumidor, de ordem pública e interesse social, nos termos dos arts. $5^{\circ}$, inciso XXXII, 170, inciso $V$, da Constituição Federal e art. 48 de duas Disposições Transitórias." (grifo nosso).

iAs Veja MOURA RAMOS, La protection, p. 206: "Le fait est qu'en droit interne la protection de la partie contractuelte la plus faible cherche à corriger un désavantage qui existe entre les deux parties, et dont le contractant plus fort peut être tenté de se prévaloir à l'égard de son coconctrant. La recherche de l'équilibre se fait donc par la construction d'un statu plus protecteur (inégale, donc) pour ce qui est la partie plus faible. On compense ainsi l'inégalité de fait par une inégalité de droit (qui devient donc compensatrice) en vue d'arriver à l'égalité au moins à l'équilibre. "Completando essa orientação, LECLERC, La protection, p. 285 , assinala que, "leur objectif ne se limite pas à l'établissement de relations contractuelles loyales et équitables, mais poursuit la réalisation de politiques qui mettent en jeu des intérêts étatiques."

146 FALLON, Marc, Le droit des rapports internationaux de consommation. In: Journal du Droit International, Paris: Editions Techniques, 1984, p. 773. Segundo o autor (p. 773), "la police de la consommation se compose de l'ensemble des dispositions impératives qui tantôt restreigent la liberté de l'industrie et du commerce dans le but de protéger les intérêts du destinataire final pris individuellement, tantôt réglementent les actes de consommation dans le but de politique économique. Comme le droit de la concurrence et la police du commerce, c'est le fonctionnement du marché économique qu'affecte la police de la consommation. (...) Ce qui la caractérise (la consommation), c'est surtout l'intérêt à protéger, à savoir le destinataire final de l'activité économique."

347 Veja NEUMAYER, Karl $H$. Autonomie de la volonté et dispositions impératives en droit international privé des obligations. Revue Critique de Droit International Privé, Paris, n. 4, p. 579-604, 1957, p. 581.

148 CALAIS-AULOY, Jean; STEINMETZ, Frank. Droit de la consommation. 5 ed., Paris: Dalloz, 2000, p. 40. No original: "la protection des consommateurs est organisée, pour l'essentiel, sur le plan national."

149 "Ant. $5^{\circ}$. XXXIl - O Estado promoverá, na forma da lei, a defesa do consumidor." Também o ârt. 48 do Ato das Disposiçōes Constitucionais Transitórias: "O Congresso Nacional, dentro de cento e vinte dias da promulgação da Constituiçăo, elaborara o código de defesa do consumidor." BRASIL. Constituição, 1988. Constituição da República Federativa do Brasil, de 5 de outubro de 1988, São Paulo: Atlas, 2000. 
Como ensina Nádia de Araújo, hoje a ordem pública internacional tem um efeito negativo (art. 17 da LICC/42) e um efeito positivo, de proteção estatal: "Há situações em que o interesse de proteção estatal é de tal ordem que há normas imperativas ou de aplicação imediata - lois de police- impedindo o uso da lei estrangeira. São normas que se caracterizam por serem de aplicação obrigatória, usadas em situações internacionais sujeitas a um direito estrangeiro, sendo controvertido o sentido, o alcance e o limite de sua intromissão."150 Assim é que, no caso do Brasil, alguns dispositivos do Código de Defesa do Consumidor, ${ }^{15}$ na medida em que protegem a vulnerabilidade do consumidor, ${ }^{152}$ podem ser aplicados imediatamente, por estarem em consonância, de acordo com Arrighi, com a proteção da vida e da saúde, assim como da melhora da qualidade de vida. ${ }^{153}$

A doutrina é unânime quanto á necessidade de uma atualização também metodológica- de nossa LICC de 1942. ${ }^{154} \mathrm{Em}$ matéria de consumo internacional, e suas especificidades, o direito positivado brasileiro, em especial a LICC, de 1942, é omissa, dando espaço para que o Código de Defesa do Consumidor seja aplicado de forma imediata e imperativa a casos internacionais. Vejamos alguns casos.

O caso talvez mais interessante é o do comércio eletrônico internacional de consumo. ${ }^{155}$ Apesar de parte dos doutrinadores que escrevem sobre comércio eletrônico ${ }^{156}$ mencionar que a regra nestes contratos seria a da autonomia da

150 ARAĹJJO, Direito, p. 97.

i5l Para Haddad, "as disposiçôes do CDC enquadram-se dentro das normas de ordem pública e já por isso näo poderiam deixar de ser aplicadas às relaçōes de consumo que envolvessem consumidores residentes no território nacional." HADDAD, Marcelo Mansur. Os vícios de produto nos contratos de compra e venda internacional: uma análise do direito comparado. Revista de Direito do Consumidor, São Paulo, n. 23-24, jul/dez. 1997, p. 182.

352 Após discorrer sobre os três princípios básicos do CDC, o princípio da vulnerabilidade, o da boa-fé e o do equilíbrio contratual, Marques, refere que "o primeiro tem reflexo direto no campo de aplicação do CDC, isto é, determina quais relaçōes contratuais estarão sob a égide desta lei tutelar e de seu sistema de combate ao abuso." MARQUES, Cláudia Lima. Notas sobre o sistema de proibição de cláusulas abusivas no Código brasileiro de defesa do consumidor (entre a tradicional permeabilidade da ordem jurídica e o futuro pósmoderno do direito comparado). Revista Jurídica, Săo Paulo, ano 47, n. 268, fev. 2000, p. 45. Veja também CHAZAL, Vuinerabilité, p. 243.

153 ARRIGHI, Jean Michel. La proteccion de los consumidores y el Mercosul. Revista de Direito do Consumdor, Săo Paulo, 1. 2, 1992, p. 131.

is4 Veja RODAS, João Grandino, Falta a lei de introdução ao Código Civil, in Gazeta Mercantil, 21.08.2001, p. 2 e, do mesmo atutor, Elementos de Conexão do direito internacional privado brasileiro relativamente às obrigaçöes, in RODAS (Ed.), Contratos Internacionais, 3.ed, RT, Sảo Paulo, p. 62-64.

155 Sobre o tema, veja MARQUES, Confiança,p. 303 e seg.

15s Veja, por todos, BARBACALO, Erica Brandini. Contratos eletrônicos. Săo Paulo: Saraiva, 2001, p. 25 e BENEVIDES DE CARVALHO, Rodrigo. A internet e as relaçöes de consumo. Internet: o direito na era virtual. In: SCHOUER, Luis Eduardo (Org.) Rio de Janeiro: Forense, 2001, p. 108, o qual afirma categoricamente: "A operação se regerá pelo princípio do pacta sunt servanda. Nesse sentido, ainda que tais cláusulas impliquem violação fagrante às normas do CDC, tal legislaçăo não poderá ser invocada, prevalecendo as obrigações tal como propostas pelo fomecedor estrangeiro e aceitas pelo consumidor." 
vontade, isto é, da possibilidade do fornecedor estrangeiro escolher a lei aplicável ao contrato (geralmente a de seu país sede) e incluir nas condições gerais contratuais ou no contrato de adesão oferecido na rede, tal interpretação da LICC/42 não é majoritária ou existente na prática dos contratos de consumo (a não ser em caso de fuga do foro brasileiro, quando a disputa é solucionada em outro foro, justamente para fugir da aplicação das normas de DIP brasileiras ou forum shopping). Em outras palavras, segundo a opinião majoritária da doutrina brasileira de DIP,, 157 as normas da LICC/42 são obrigatórias (leis federais) e aplicável seria o art. $9^{\circ} \mathrm{da} \mathrm{LICC} / 42$, a excluir a autonomia da vontade nos contratos internacionais em geral, quanto mais os de consumo.

Em matéria de contratos de consumo, há que se considerar que a constituição de 1988 atualizou os princípios do DIP brasileiro. Assim, por tratar-se de direito fundamental a proteção do consumidor reconhecido pela Constituição da República de 1988 (art. 5 XXXII) e o CDC, lei de origem constitucional (art. 48 dos Atos das Disposições Constitucionais Transitórias $\mathrm{ADCT}$ ), é bem possível que tais normas sejam consideradas "imperativas"1.58, de ordem pública internacional ${ }^{159}$ ou leis de aplicação imediata, aplicando-se, pois, neste último caso, mesmo antes das normas de DIP ao caso.

Especial atenção merece o fato de o mandamento de proteção do consumidor, como direito fundamental a obrigar o Estado-Legislador, o EstadoJuiz e o Estado-Executivo a uma ação positiva na tutela destes agentes vulneráveis do mercado brasileiro, estar incluído no inciso XXXII do art. $5^{\circ}$ da Constituição Federal (artigo que em seu caput assegura estes direitos a brasileiros e a estrangeiros residentes no Brasil). Daí se retira que a nova ordem pública constitucional brasileira inclui necessariamente a "defesa do consumidor". A pergunta é o grau, o nível ou o standard desta proteção em casos de Direito Internacional Privado. Em outras palavras, a pergunta é se em casos pluriconectados, todas as normas do Código Brasileiro de Defesa do Consumidor, seriam imperativas ou de ordem pública internacional (grau total de aplicação), ou se somente a preocupação de "defesa do consumidor" seria obrigatória, podendo ser alcançada pela aplicação eventual de uma lei estrangeira, indicada aplicável pelas normas da LICC/42. Em outras palavras, o nível de defesa do consumidor, alcançado pelo CDC, é considerado, em face da sua origem constitucional (art. 48 ADCT), como obrigatório a tutelar os

157 Veja, por todos, ARAÚJO, Nádia de. Contratos Internacionais - Autonomia da Vontade, Mercosul e Convençōes Internacionais, Renovar, Rio de Janeiro, 1997, p. 108 e seg.

${ }_{158} \mathrm{O}$ Brasil ainda năo ratíficou a CIDIP do México de 1994 sobre contratos internacionais, que expressamente prevê, em seu art. 11, que as normas nacionais imperativas (mandatory rules) afastam a eventual autonomia de vontade, conexăo principal da CIDIP. Veja sobre a Convençăo, ARAÚlO, Contratos, p. 108 e seg.

159 A exceção de ordem pública tem um claro fim social e de proteção, não só do sistema do DIP, mas tambén, nos países da família de direito continental-europeu, das políticas públicas ou objetivos de hamonia social interna, BUCHER, p. 60-69. 
brasileiros e estrangeiros (pessoas físicas) residentes no Brasil, como standard mínimo imperativo de "defesa do consumidor", o que levaria à aplicação imediata destas normas tutelares.

A solução do Art. 29a da EGBGB alemã é mais positiva, pois induz a uma cumulação de normas protetivas do consumidor, isto é, não impede a aplicação de normas estrangeiras, se assegurarem um nível superior de defesa ao alcançado pela diretiva européia ou norma imperativa nacional, no caso, o CDC. ${ }^{160}$ Assim, a conclusão do $5^{\circ}$ Congresso Brasileiro de Direito do Consumidor/Brasilcon,: "11. As normas do CDC, como expressamente consignado em seu artigo $1^{\circ}$, são de "ordem pública e de interesse social", entre a ordem pública local e a ordem pública estrangeira o juiz deve preferir a ordem pública de seu país; as disposições do CDC, por serem normas de ordem pública, não podem deixar de ser aplicadas às relações de consumo que envolvem consumidores residentes no território nacional, ressalvada a aplicação cumulativa da legislação estrangeira mais favorável. (aprovada por unanimidade)". ${ }^{161}$

Para o nosso exame, interessante notar que as normas do CDC são de ordem pública interna (art. $1^{\circ}$ ), que os artigos $2^{\circ}$ e $3^{\circ}$ do Código de Defesa do Consumidor denotam sua aplicação a todos consumidores finais, nacionais ou estrangeiros (independente de sua nacionalidade ou domicílio) e fornecedores, nacionais e estrangeiros. Assim, dispõe o CDC, em espírito de inclusão semelhante ao do anterior art. $3^{\circ}$ do Código Civil de $1917, t^{162}$ e com espírito de real proteção do vulnerável, sem mencionar a nacionalidade ou o domicílio dos agentes da contratação à distância: "Art. $2^{\circ}$ Consumidor é toda pessoa física ou juridica que adquire ou utiliza produtos ou serviços como destinatário final. Parágrafo único. Equipara-se a consumidor a coletividade de pessoas, ainda que indetermináveis, que haja intervindo nas relações de consumo.". E o art. 29 complementa: "Para os fins deste Capitulo e do seguinte, equiparam-se aos consumidores todas as pessoas determináveis ou não, expostas às práticas nele previstas."

Também o art. $3^{\circ}$ do Código de Defesa do Consumidor inclui como fornecedor "toda pessoa física ou jurídica, pública ou privada, nacional ou estrangeira, bem como os entes despersonalizados," que desenvolvam "atividade de produção, montagem, criação, construção, transformação, importação, exportação, distribuição ou comercialização de produtos ou prestação de serviço". Mencionados expressamente também, no art. 12 do

160 Veja von Hotfman, p. 401 e seg.

(6) Conclusōes do 50 Congresso Brasileiro de Direito do Consumidor, in Revista Direito do Consumidor, vol. 33, p. 265.

$162 \mathrm{O}$ art. $3^{\circ}$ do anterior Código Civil Brasileiro, de 1917, dispunha: "A lè nāo distingue entre nacionais e estrangeiros quanto à aquisiçăo e ao gozo dos direitos civis." Infelizmente este artigo näo foi repetido pelo novo Codigo Civil brasileiro, que entrou em vigor em 1 a de janeiro de 2003. 
CDC, estão os fabricantes, produtores e construtores estrangeiros e o importador de produtos estrangeiros. Parece-nos que todos estes artigos denotam a "vontade" do Código de Defesa do Consumidor em ser aplicado também aos casos de consumo internacional ocorridos no mercado brasileiro ou com os consumidores que protege, como norma de aplicação imediata. ${ }^{163}$

Efetivamente, o Código de Defesa do Consumidor parece fornecer padrões mínimos (e imperativos) à proteção de consumidores-passivos em todos os contratos à distância, contratos negociados no Brasil por nacionais ou estrangeiras, ou, quando o marketing ou a oferta forem feitos no Brasil, inclusive nos contratos eletrônicos com fornecedores com sede no exterior, ${ }^{164}$ como impōem o Unfair Contract Terms Act, de 1977, do Reino Unido, ou a lei alemã de 1976 (art. 12 e art. 29a da EGBGB), ${ }^{165}$ ou a lei portuguesa de 1985 (art. 33). ${ }^{166}$

Parece-nos que se a conclusão do contrato for precedida por um convite ou indução ao negócio dirigido a ele ou genérico por meio da publicidade, ${ }^{167}$ e o consumidor realizou no Brasil todas as medidas necessárias de sua parte para a conclusão do contrato (aceitação válida), a lei brasileira possui contatos mais próximos e deve ser aplicada ao contrato internacional de consumo, de forma a favorecer o contratante mais fraco. Deve ser um risco profissional do fornecedor, o qual se utiliza destas tecnologias novas e deste tipo de marketing à distância, o eventual uso das normas imperativas ou de aplicação imediata do país do domicílio ou residência habitual do consumidor, no qual a oferta à distância resultou em contratação. ${ }^{168}$ Também segundo a doutrina francesa, a proteção dos contratantes mais fracos é mais bem realizada se as normas

163 Examinando as leis alemãs de proteção ao consumidor e o novo art. 29a da Lei de tratrodução ao Código Civil alemão (EGBGB), conclui no mesmo sentido REICH, Norbert e NORDHAUSEN, Annette. Verbraucher und Recht im elektronischen Verkehr (eG), Baden-Baden: Nomos, 2000, p. 95-99.

164 Assim também sugere LORENZETTI, Ricardo Luis. Comercio electrónico. Buenos Aires: Abeledo-Perrot, 2001 , p. 256, para a Argentina.

165 Winter relembra que também as normas sobre seguros e proteção dos consumidores são imperativas na Alemanha, WINTER, Gerrit. Internationale Online-Versicherung als Korrespondenzversicherung. Versicherungsrecht, 2001, p. 1461.

166 Como ensina Pierre Mayer, p. 521, estas são leis de aplicação imediata que deteminam expressamente seu campo de aplicação, impondo sua aplicação a todos os contratos de consumo, se o conslimidor tem nestes países a sua residência habitual e realizou todos os atos de conclusão do contrato sem sair do país (consumidor passivo). Veja como o consumidor passivo no comércio eletrônico é protegido também nos Estados Unidos da América, nas leis de Onio, da Virginia e de Washington e na lei suíça, in KRONKE, p. 82-83.

167 A simples publicidade on-line, con efeitos no país, já pode violar as normas imperativas do direito do consumidor, como comprova a decisăo do Tribunal de Frankfurt (OLG Frankfurt), de 31 de maio de 2001, envolvendo publicidade de farmácia holandesa oferecendo medicamento proibido na Alemanha. Veja ZIP 2001, p. 1164-1168.

168 Veja tämbém FERNANDES, Antônio Joaquim. Responsabilidade do provedor de Internet, in Revista Direito do Consumidor, vol. 26, p. 49. 
tutelares nacionais são consideradas "leis de aplicaçāo imediata". ${ }^{169}$ A doutrina estrangeira conclui que esta é a prática da maioria dos países do primeiro mundo. ${ }^{170}$

Parte da doutrina sobre comércio eletrônico considera esta aplicação direta do Código de Defesa do Consumidor demasiadamente extensiva e defende a aplicação das regras tradicionais nacionais de conflitos de lei. ${ }^{171}$ Apoiando a solução da LICC de 1942, e a aplicação da lei do fornecedor (ou porque propöe o contrato - art. $9^{\circ}, \S 2^{\circ} \mathrm{da}$ LICC -, ou porque escolhe a sua lei no contrato - autonomia da vontade em DIP - ou porque tem a conexão mais estreita ao realizar a prestação característica - lei do lugar da execução , consideram estes autores que é risco do consumidor fazer uma transação à distância internacional e a aplicação da lei mais favorável ao fornecedor é uma conseqüuência aceitável. ${ }^{172}$

Já, a doutrina consumerista ${ }^{173}$ geralmente desconhece a teoria das leis de aplicação imediata em DIP e defende - de lege ferenda - a aplicação da lei local do domicílio ou a residência do consumidor, se a oferta for feita no Brasil ${ }^{174}$, ou que as normas do CDC são de ordem pública internacional. ${ }^{175}$

Efetivamente, a jurisprudência brasileira tem aplicando o CDC a casos pluriconectados, antes do recurso à Lei de introdução, como lei de aplicação imediata. Especificamente sobre contratação à distância na jurisprudência

159 Assin conclui MAYER, p. 331 .

170 Veja, por todos, KRONKE, p. 82. Assim concl lii até mesmo o advogado da Microsof, em seu Curso de Haia de 2001, $5 \mathrm{MIFH}$, Bradford. The third industrial revolution: Law and policy for the Internet. Recueil des Cours de l'Acadénie de Droit Intemational de la Haye. Paris: Recueil, 2000, T. 282, p. 330, mesmo protestando contra esta prática e pedindo que a lnternet seja regulada de forma mínima.

$"$ Cf. GRECO, Marco Aurélio. Direito e internet. São Paulo: Dialética, 2000 p. 50.

17 Veja GRECO, 2000, p. 50 e BENEVIDES DE CARVALHO, p. 108.173 Veja, por todos, MARTINS CASTRO, Luiz Fernando. O Comercio Eletrônico e a Defesa do Consumidor Brasileiro e no Mercosul, in Internet e Direito - reflexöes doutrinarias, Rodrigo Rodrigues da Silva Junior (Coord.), Lumen Júris, Rio de faneiro, 2001 , p. 138-139.

${ }^{1 / 4}$ Assim LUCON, Paulo Herrique dos Santos. Competência no comércio e no ato ilícito eletrônico, in DE LUCCA, Newton e SIMÃO FlLHO, Adalberto, Direito e Internet- Aspectos Jurídicos Relevantes, São Paulo, Edipro, 2000, p. 351-370, p. 354-355.

:75 Esta é uma teoria francesa do inicio do século XX: "les lois d'intérêt général qui s'imposent toujours à son observation sur le territoire ou elles ont été edictées. Nous comprendrons ces dernières sous le nom de lois d'ordre public international." Assim André Weiss apud Anderegg, Kirsten, Ausländische Eingriffsnom im internationalen Vertragsrecht, Ed. Mohr, Tübingen, 1989, p. 9. Sobre Código de Bustamante, veja Samtleben, Jügen, Derecho Internacional Privado en América Latina - Teoría y Práctica del Código Bustamante, Depaima, vol. 1, Buenos Aires, 1963, p. 270, ${ }^{1 \%}$ Assim a decisão do 1o TACivSP, 24.17.98, Juiz. Antonio de Pádua Ferraz: "PRESTAÇÃO DE SERVIÇOS - TELESEXO DDI - Empresas estrangeiras fornecedoras do serviço se submetem à lei brasłleira, notadamente o Código de Defesa do Consumidor, que veda a prestação de serviço sem a solicitação prévia - Inaplicabilidade do art. 129 do Código Civil Inteligência dos art. 1 e 39 抽 e parágrafo único da Lei 8.078/90." in Revista dos Tríbunais, vol. 765, p. 231-234. Veja também sobre telefonia decisóes do Tribunal de Justiça de São Paulo, in Revista Direito do Consumidor, vol. 34, p. 311 e in Revista Direito do Consumidor, vol. 35, p. 347. 
brasileira, o número de casos ainda é pequeno, mas é necessário mencionar o rumoroso caso de contratação de serviços internacionais de lazer aos consumidores, conhecido como "caso do telessexo internacional". Neste caso, fornecedores de serviços dos países nórdicos estavam oferecendo "serviços sexuais" via telefone, no mercado brasileiro, através de um fornecedor de serviços telefônicos nacional (a Telebrás). Os custos deste serviço internacional eram pagos através das contas normais do telefone, fazendo com que, desse modo, o $1^{\circ}$ TACiv. de São Paulo decidisse que o fornecedor responsável era a empresa brasileira de telefonia (fornecedor aparente), aplicando o Código de Defesa do Consumidor a estes contratos internacionais de consumo. ${ }^{176}$

O leading case em matéria de produtos e serviços estrangeiros e o standard mínimo de proteção dos consumidores é sobre um consumidor ativo, um caso envolvendo um turista brasileiro que retorna ao mercado brasileiro com o produto defeituoso. Nesta decisāo líder, o Superior Tribunal de JustiçaST] responsabilizou a filial brasileira pela garantia de produto adquirido nos Estados Unidos da Amércia (distribuído pela matriz no Japão e produzido possivelmente na Indonésia ou na China), de marca famosa e mundial (Panasonic), tudo segundo o Código Brasileiro de Direito do Consumidor, considerado neste caso, implicitamente, como "lei de aplicação imediata".

\section{ANÁLISE DO CASO PANASONIC}

O caso Panasonic ${ }^{177}$ é denominado por muitos como leading case na matéria ${ }^{178}$ Diz respeito à compra de uma filmadora, da marca Panasonic, em Miami, por um turista brasileiro, sendo que, após seu regresso ao Brasil, a filmadora apresentou vícios. O consumidor brasileiro intentou uma reparação de danos contra a Panasonic do Brasil. ${ }^{179} \mathrm{Na}$ decisão do caso, foi aplicado o Código de Defesa do Consumidor brasileiro, sem qualquer referência ao artigo $9^{\circ}$ da Lei de Introdução ao Código Civil (LICC), que indica a lei aplicável às obrigações. Propõe-se a análise e discussão dos fundamentos jurídicos que embasaram esta decisão, perquerindo-se acerca da adoção da legislação brasileira como norma de aplicação imediata.

No Brasil, a aplicação do método das normas de aplicação imediata pode ser constatada, no que concerne à defesa do consumidor, no REsp. 63981/

${ }^{177}$ REsp. n ${ }^{\circ}$ 63.981-SP, do Superior Tribunal de lustiça. Publicado na RSTl, Brasília, ano 12, n. 137, jan. 2001, p. 387-492. Ementa publicada in MARQUES, Cláudia Lima, BENIAMIN, Antonio H. de V. e MIRAGEM, Bruno, Comentários ao Código de Defesa do Consumidor-Art. 1 a 74 -Aspectos materiais, São Paulo: RT, 2004, p. 109 e 110.

178 Veja MARQUES, A proteção, p. 724 e ARAÚJO, Direito, p. 19.

179 Sobre a repercussão do caso quanto à tutela da confiança, vejà IACQUES, Daniela Corrêa. A proteçăo da confiança no direito do consumidor. Revista de Direito do Consumidor, n. 45, p. 100-128, jan./mar. 2003, p. 115. 
SP (caso Panasonic), julgado pelo Superior Tribunal de Justiça. Neste caso, a decisão expressamente reconheceu as particularidades internacionais da relação, optando por uma aplicação da legislação interna (o Código de Defesa do Consumidor). Esse reconhecimento pode ser observado na ementa da decisão:

"I-Se a economia globalizada não mais tem fronteiras rígidas e estimula e favorece a livre concorrência, imprescindivel que as leis de proteção ao consumidor ganhem maior expressão em sua exegese, na busca do equilibrio que deve reger as relaçöes jurídicas, dimensionando-se, inclusive, o fator risco, inerente à competitividade do comércio e dos negócios mercantis, sobretudo quando em escala internacional, em que presente empresas poderosas, multinacionais, com filiais em vários países, sem falar nas vendas hoje efetuadas pelo processo tecnológico da informática e no forte mercado consumidor que representa o nosso País."

No mesmo sentido, no voto do Ministro Aldir Passarinho Júnior:

"A questão fundamental que surge, é que a mercadoria em discussão - máquina filmadora - não foi nem comprada no Brasil, nem tampouco, de empresa que a produziu, comercializou ou garantiu. Trata-se de uma relação de consumo realizada, por inteiro em Miami, Estados Unidos da América, em que circunstancialmente, o Autor-recorrente é domiciliado no Brasil."

Nesse voto, que diverge do entendimento da decisāo final, o Ministro coloca o seguinte questionamento próprio do direito internacional privado:

"Como, portanto, aplicar um Código de Defesa do Consumidor brasileiro a um negócio feito no exterior, entre uma empresa estrangeira e um turista brasileiro? (...) Assim tenho que a Lei n. 8.078/1990 não alcança a relação de consumo contratada no exterior, nos termos aqui configurados (sem ressalva contratual em contrário), inaplicáveis à espécie, por impertinentes ao caso, os arts. $3^{\circ}$ e $28, \S 5^{\circ}$, do citado diploma."

Deve ser apontado, que, em nenhum momento, houve qualquer mençāo ao recurso das normas conflituais, dispostas na LICC brasileira, mormente o artigo $9^{\circ}$ caput, ${ }^{180}$ que cuida dos contratos internacionais. Por esse dispositivo,

1 180 "Art. 90 Para qualificar e reger as obrigaçöes, aplicar-se-á a lei do país em que se constituírem." Lei de Introdução ao Código Civil brasileiro, Decreto-lei $n^{\circ} 4,657$, de 4 de setembro de 1942 . 
considerado, pela doutrina, como obrigatório, ${ }^{181}$ a lei aplicada deveria ter sido a da Florida, local onde fora realizada a compra da filmadora. ${ }^{182}$ Entretanto, a lei da Florida nem se quer foi suscitada na fundamentação da decisão. O litígio internacional foi resolvido como se nacional fosse. ${ }^{183}$

Assim, pode-se afirmar que os dispositivos do Código de Defesa do Consumidor brasileiro foram aplicados como norma de aplicação imediata. Os fundamentos de aplicação, além do caráter imperativo, que justificaram a aplicação da legislação brasileira, estruturaram-se no domicílio do consumidor e da empresa demandada. ${ }^{184}$ Por outro lado, frisa-se também a importância da proteção da confiança do consumidor brasileiro que adquiriu o produto em Miami da marca Panasonic. ${ }^{185}$

Essa solução, adotada no caso, poderia implicar uma aplicação irrestrita das normas de proteção do consumidor para todas as relaçōes internacionais como normas de aplicação imediata, cujo entendimento é fortemente criticado pela doutrina por perder de vista o objetivo da harmonia jurídica internacional ${ }^{186}$ e algumas especificidades da relação internacional. ${ }^{187} \mathrm{Nem}$ todo o direito do consumidor de determinado país tem caráter de imperatividade a ponto de justificar a sua aplicação sempre como norma de aplicação imediata. ${ }^{188}$

Além disso, salienta Fallon que essa solução poderia criar dificuldades práticas que afetariam diretamente à essência do contrato, como certas regulações de cláusulas contratuais, sejam de condiçōes gerais ou cláusulas abusivas, que por sua amplitude poderiam afetar diferentes aspectos do contrato, como a formação, execução e extinção, sem, contudo, fornecer uma regulação completa. ${ }^{189}$ Trata-se, como se refere Leclerc, da própria coerência do contrato. ${ }^{190}$

iB: Veja MARQUES, Contratos, p. 127.

:82 Assim também ARAÚlO, Direito, p. 19.

is: Essa é uma das caracteristicas das normas de aplicaçăo imediatà Veja MOURA RAMOS, La protection, p. 225.

184 Assim o voto-vogal do Ministro Ruy Rosado de Aguiar: "No caso dos autos, o consumidor adquiriu um produto Panasonic em outro pals, internalizotwo e hoje o aparelho apresenta defeito. A Panasonic do Brasil, que o próprio nome já indica pertencer ao mesmo grupo da empresa fabricante, embora com sede em outro lugar, tem a responsabilidade de cumprir com a obrigação de assistencia assumida pelo fabricante. Nem sequer é necessário tecorrer à desconsideração da pessoa jurídica (aplicável à hipótese nos termos do art, $28, \S 5^{\circ}$, do $\mathrm{CDC}$ ), uma vez que se trata do mesmo grupo societário, 'empresas vinculadas à mesma matriz', conforme admitido nos autos, razão pela qual a fillat estabelecida no Brasil aqui responde subsidiariamente pelas responsabilidades previstas no Código, na forma do art. 28 , $2^{\circ}$."

18̄̄ Veja JACQUES, A proteção, p. 124: "No caso da Panasonic, em nenhum momento, o consumidor acreditou que a Panasonic de Miami-EUA e a Panasonic do Brasil se tratava da mesma personalidade jurídica, entretanto somente adquitiu o produto Panasonic porque a marca lhe getava confiança e em razāo dessa confiança que procurou a responsabilização da Panasonic do Brasil."

186 MARQUES, A proteçäo, p. 687; MOURA RAMOS, La protection, p. 223 e l. ECLERC, la protection, p. 257.

18\% MARQUES, Contratos, p. 124-5.

:88 MARQUES, Contratos, p. 132.

189 FALLON, Le droit, p. 842.

190 LECLERC, La protection, p. 349. 
Em síntese, aA decisão do caso Panasonic (REsp. 63.981-SP), com a aplicação imediata do Código de Defesa do Consumidor brasileiro a uma relação contratual de consumo, realizada no exterior por um consumidor-ativo, se, por um lado, demonstra a importância da proteção da confiança e da responsabilidade em razão da marca do produto, ${ }^{191}$ por outro, espelha a constatação de que as normas conflituais clássicas, consubstanciadas, no Brasil, na Lei de Introdução ao Código Civil (LICC) de 1942, não são o método exclusivo do direito internacional privado, convivendo com as normas de aplicação imediata. Sob esse aspecto, a decisão do caso, relativamente à aplicação dos dispositivos internos de proteção ao consumidor como norma de aplicação imediata, representa uma recusa implícita do direito internacional privado brasileiro de continuar a usar para a proteção internacional do consumidor as conexões rígidas e antigas contidas nas normas da LICC de 1942. O que se constatou, no entanto, no caso apresentado, foi uma certa ausência ou mesmo escassa referência aos métodos do direito internacional privado na argumentação apresentada pelos julgadores e uma forte noção da necessidade de uma ordem pública positiva de proteção dos consumidores, a reforçar a importância do estudo da problemática das normas de aplicação imediata no direito internacional privado brasileiro.

\section{CONSIDERAÇÕES FINAIS}

Da análise realizada, conclui-se que no caso de um ordenamento jurídico com poucas normas de caráter bilateral, com conexões rígidas e antigas, como é o caso do Brasil, cuja LICC é de 1942, ( e que nada mencionam sobre o consumidor - sujeito desconhecido à época), ${ }^{192}$ a adoção do método das normas de aplicação imediata para a proteção do consumidor significa um passo importante e talvez necessário até a elaboração de normas especiais.

A despeito de todas as críticas expostas relativamente à conveniência de proteger o consumidor por meio das normas de aplicaçāo imediata, ${ }^{193}$ elas representam uma solução plausível, em tanto que oposição ao método clássico conflitual bilateral, ${ }^{194}$ já adotadas pela Europa e Estados Unidos. ${ }^{195}$ Conforme

\footnotetext{
191 JACOUES, A proteçäo, p. 111.

19? MARQUES, Contratos, p. 123.

193 Veja também LECLERC, La protection, p. 355.

${ }^{194}$ Assim os comentários de MAYER, Les lois, p. 114: "Les lois de police paraissent être entrées dans une phase critique de leur existence. L'hostilité qu'elles suscitent est vive, puisque leurs adversaires sont animés à la fois par la volonté de défendre la liberté du commerce international, par la crainte des complications diplomatiques, et peutütre encore par un certain classicisme respectueux de la méthode savignienne. A tout cela s'oppose le seul souci de la défence des intérêts da la partie la plus faible et des intérêts généraux, tels que les a apprécies ['État dans la sphère duquel ils se situent. Il faut espérer que son poids ne sera pas négligé dans l'établissernent de la balance finale, dont dépend l'avenir de la méthode des lois de police."

is.5 Veja GUED\}, The theory, p. 683.
} 
revela Fallon, em matéria de proteção do consumidor, a utilização dessas normas já é uma realidade. ${ }^{196}$

O uso das normas de aplicaçäo imediata, no Brasil, representa uma orientação no sentido de seguir a denominada tendência materialista no direito internacional privado. Deve-se atentar, no entanto, ao uso moderado desse método. Pretende-se, assim, assegurar um nível de proteção ao consumidor, no plano internacional, equivalente àquele estabelecido para o âmbito interno. ${ }^{197} \mathrm{Na}$ visão de Fausto Pocar, as normas de aplicação imediata imporiam apenas um mínimo de proteção, não excluindo, dessa forma, a utilização de regras mais protetivas ao consumidor. ${ }^{198}$ Uma solução legislada, conflitual clássica ou mista, como a do Art. 29a da EGBGB, ofereceria mais segurança e efetividade, dai sugerirmos que seja inclúfda uma norma especial de defesa do consumidor na LICC/42. ${ }^{199}$

Metodologicamente, o direito internacional privado clássico se estruturou cientificamente na forma do método conflitual. Também é certo afirmar hoje que existem muitas outras normas de DIP, um DIP de segunda geração ou, na expressão de Siehr, um DIP em dois níveis (Zweitstufigkeit des IPR), ${ }^{200}$ normas materiais (de direito civil, de direito do consumidor, de direito comercial) feitas especialmente para aplicarem-se em casos internacionais ou que se aplicam de forma imediata, mandatória e direta aos casos atípicos. Regular os conflitos de leis não mais apenas indiretamente, mas diretamente, por normas de aplicação imediata e outros métodos novos, como o representado pelo Art. 29a do EGBGB, é uma das caracteríticas do DIP no século XXI, visando sempre

195 FALLON, Le droit, p. 842.

9\% MOURA RAMOS, ta protection, p. 225.

9 POCAR, Fausto. La protection de la partie faible en droit international privé. Recueil des Cours de l'Academie de Droit International de la Haye, 1984, t. 188. Dordrecht/Boston/London: Martinus Nihoff Publishers, 1986, p. 400.

*s: Veja sugestão de MARQUES, Confiança, p. 470 e 471: "Art. 9bis [Proteção contratual dos consumidores] Os contratos e as transaçôes envolvendo consumidores, especialmente os contratados à distância, por meios eletrónicos, de telecomunicaçōes ou por telefone, estando o consumidor em seu país de domicílio, serão regidos pela tei deste país ou pela lei mais favorável ao consumidor, escolhida entre as partes, se lei do lıgar da celebraçăo do contrato, lei do lugar da execução do contrato, da prestaçäo característica ou lei do domicílio ou sede do fornecedor de produtos e serviços. $\$ 1^{\circ}$. Aos contratos celebrados pelo consumidor estando fora de seu país de domicílio será aplicada a lei escolhida pelas partes, dentre a lei do lugar de celebração do contrato, a lei do lugar da execução e a lei do domicitio do consumidor. $\$ 2^{\circ}$. Em todos os casos, aplicar-se-á necessariamente as nomas do país do foro que tenham caráter imperativo, na proteção do consumidor. $\$ 3^{\circ}$. Tendo sido a contratação precedida de qualquer atividade negocial, de marketing, do fomecedor ou de seus representantes, em especial envio de publicidade, correspondências, e-mails, prêmios, convites, manutenção de filial ou representantes e demais atividades voltadas para o fornecimento de produtos e serviços e atração de clientela no país de domićlio do consumidor, aplicar-se-á necessariamente as normas imperativas deste pás, na proteçào do consumidor, cumulativamente àquelas do foro e à lei aplicável ao contrato ou relação de consumo."

wo SHEHR, Kurt, Internationales Privatrecht, C.F. Müller, Heidelberg, 2001, p. 360 (\$44, n.4). 
à justiça do caso concreto. O método conflitual não é mais o único, ${ }^{201}$ nem a norma conflitual é a única norma de DIP hoje, ${ }^{202}$ fenômeno que Erik Jayme denomina, com razão, de tendência à materialização do DIP. ${ }^{203}$

Acrescente-se aqui a importância do estudo do direito do consumidor, neste contexto. A importância dos ensinamentos de Marques dos Santos no Brasil deve ser ressaltada, entre outras contribuiçōes, no que se refere à autonomia do método das normas de aplicação imediata, implicando um tratamento unitário e autônomo a estas regras. ${ }^{204}$ Assim, ganha relevância o emprego das normas de aplicação imediata, aplicando-se alguns dispositivos internos do ordenamento do foro imediatamente (sem o intermédio do método conflitual clássico) para solucionar materialmente os casos próprios do direito internacional privado, especialmente se envolvendo valores constitucionais como no Brasil.

201 BATIFFOL, Le pluralisme..., p. 79.

202 Concorda ARAÚlO, Direito..., p. 48.

203 JAYME, Recueil, p. 44.

204 Veja sobre a importância de responder a esta chamada crise metodológica do DIP, KEGEL, Gerhard. The crisis of conflict of laws. Recueil des Cours de l'Academie de Droit International de la Haye, 1964, t. 112, Leyden: A. W. Sijhoff, 1964, p. 237. 